\title{
Vattimo y el anuncio heideggeriano de la eventualidad del ser ${ }^{\top}$
}

\author{
Vattimo and the heideggerian announcement \\ of the eventuality of being
}

\author{
ANTONIO BUENO GONZÁLEZ \\ Universidad Nacional de Educación a Distancia (España)
}

recibido: 18.05 .2018

aceptado: 24.10 .2018

\section{RESUMEN}

La indagación del segundo Heidegger acerca del ser encuentra su maduración en la doctrina del Ereignis, un nuevo concepto «post-metafísico», según Vattimo, con el que el filósofo alemán trata de responder a la pregunta de qué es el ser una vez ha mostrado, en su primera etapa intelectual, la esencial diferenciación ontológica. El ser no es un ente, ni aquello fijo e inmutable que fundamenta lo ente. Ni de él puede decirse que es; el ser «se da». Y se da al hombre en un acto de donación recíproca en la totalidad del acontecer histórico. Vattimo parte de esta idea para concluir que el ser es evento que orbita en la constelación del Ge-Stell, el destino de la época actual en cuanto forma de desocultar el ser, de desvelar la verdad, y convierte a Heidegger en precursor de la postmodernidad y de su pensiero debole.

\section{PALABRAS CLAVES \\ EREIGNIS; GE-STELL; SER; POSTMODERNIDAD}

\begin{abstract}
The second Heidegger's inquiry about being finds its maturation in the doctrine of Ereignis, a new «post-metaphysical» concept, according to Vattimo, with which the german philosopher tries to answer the question of what being is, once he has shown, in its first intellectual stage, the essential ontological differentiation. The being is not an entity, nor that fixed and immutable that grounds the entity. Neither of it can be said to be; the being «is given». And it is given to man in an act of reciprocal donation in the totality of historical events. Vattimo starts from
\end{abstract}

1 Este estudio continúa, actualiza y completa una investigación que se inició como TFM, que se defendió en 2012, y en cuya línea he seguido trabajando los últimos años.

Claridades. Revista de filosofía 11 (2019), pp. 141-188

ISSN: 1889-6855 ISSN-e: 1989-3787 Dl.: PM 1131-2009

Asociación para la promoción de la Filosofía y la Cultura (FICUM) 
this idea to conclude that the being is an event that orbits in the constellation of Ge-Stell, the destiny of the present time as a way of uncovering the being, of revealing the truth, and converts Heidegger into a precursor of postmodernity and his pensiero debole.

KEYWORDS

EREIGNIS; GE-STELL; BEING; POSTMODERNITY

\section{INTRODUCCIÓN}

«Pensamiento DÉBIL», «ontología del declinan», «ontología decadente» y «ontología débil» son los diversos modos de nombrar a la filosofía de Vattimo. El pensamiento de este autor, uno de los que conforman la filosofía de la postmodernidad, mantiene diferencias notables respecto a los demás filósofos postmodernos. Quizás lo que más acentúa estas diferencias es su intento de conferir «rigor y dignidad filosófica (a) las dispersas y no siempre coherentes teorizaciones del período postmoderno ${ }^{2}$. Para lograr este objetivo, cree necesario vincular el desarrollo del pensamiento postmoderno con la problemática nietzscheana del eterno retorno y con la problemática heideggeriana del rebasamiento de la metafísica.

En mi opinión, Vattimo es el filósofo que con mayor claridad ha explicitado la vocación de la postmodernidad por su puesta en relación con la ontología hermenéutica de Nietzsche y Heidegger ${ }^{3}$. La referencia a Nietzsche es, sin lugar a dudas, el nexo común a las dos corrientes de pensamiento que integraron este movimiento filosófico a partir de los años $60 \mathrm{del}$ siglo pasado: hermenéutica y postestructuralismo. La referencia a Heidegger es, por el contrario, más controvertida y problemática. Sin embargo, Vattimo lo considera un autor esencial para comprender la postmodernidad, la cual se anuncia en Ser y tiempo y madura en las obras posteriores, agrupadas bajo la denominación del Segundo Heidegger. En su opinión, las aportaciones de Heidegger, conjuntamente con las de Nietzsche, son las que han contribuido al establecimiento del rasgo más característico del pensamiento postmetafísico: el debilitamiento del ser, al que sólo puede atender un pensamiento débil. Estas aportaciones se resumen en cuatro: el rechazo a la fundamentación según la filosofía occidental de tipo pla-

2 Vattimo, G., El fin de la modernidad, Gedisa, Barcelona, 1996, p. 9.

3 Sigo aquí a la profesora Teresa Oñate, Estudio Preliminar de la obra Nietasche contra Heidegger. Ontología estética, Dykinson, Madrid, 2008, pp. 13-47. 
tónico, el nihilismo, el rechazo a la subjetividad moderna y la disolución de la idea de una historia como proceso unitario ${ }^{4}$. Aquí estudiaremos sólo la aportación del primero de ellos, por lo que es esencial comenzar por la interpretación que el filósofo italiano hace de él.

\section{I.1. LA INTERPRETACIÓN VATTIMIANA DE HEIDEGGER}

Tradicionalmente, la crítica ha dividido el pensamiento de Heidegger en dos etapas. El primer Heidegger, que culmina en Ser y tiempo (1927), estaría influido por el neokantismo, la fenomenología de Husserl, el historicismo de Dilthey y el existencialismo de Kierkegaard. El segundo Heidegger, el que arranca tras la llamada Kehre (vuelta) del pensar, comienza a mediados de los años 30 con obras como Sobre la esencia de la Verdad o El Origen de la Obra de Arte y se expresa explícitamente en la Carta sobre el bumanismo (1947), «Tiempo y ser» (1962), Identidady Diferencia (1957), entre otras conferencias y otros escritos. Esta segunda etapa fraguaría bajo la influencia de Nietzsche, cuyo pensamiento resulta ya esencial como tema dominante en el desarrollo de su pensamiento entre 1935 y 1943. Incluso, se ha llegado a hablar de dos filosofías completamente diferentes ${ }^{5}$.

Vattimo plantea dos interpretaciones posibles de la Kehre 6 : a) «interna», que niega que haya una fractura interna entre el Heidegger de Sery tiempo y el de las obras posteriores y b) de tipo biográfico-político, que relaciona el abandono de las posiciones de la citada obra con la adhesión de su autor al nazismo. La interpretación «interna», que es la que defiende, sostiene que el interés de Sery tiempo es ya puramente ontológico, puesto que el análisis de la existencia se orienta a la reproposición del problema del ser. Además, en dicha obra hay una negación de cualquier posible trascendentalismo, de cualquier doctrina del sujeto. La Kehere ontológica identifica dos nociones de sujeto que Heidegger había contrapuesto anteriormente: el individuo o sujeto cristiano-burgués y el sujeto trascendental. Ambas nociones tienen

4 Cfr. Berciano, M., «Heidegger,Vattimo y la deconstrucción», Anuario Filosófico, 1993 (26), p. 10.

5 Cfr. Manuel Garrido, Introducción a Tiempo y ser, de Martin Heidegger, Tecnos, Madrid, 1999, Trad. Española de Manuel Garrido, Félix Duque y José Luis Molinuevo, p. 9 y ss. Tiempo y ser es la traducción española de Zur Sache des Denkens (El asunto del Pensar), M. Niemeyer, Tübingen, 1969, obra que contiene la conferencia «Tiempo y ser».

6 Vattimo, G., Las aventuras de la diferencia. Pensar después de Nietzsche y Heidegger, Península, Barcelona, 1985 , p. 52 y s. 
las mismas raíces y la negación de una lleva al la negación de la otra.

El filósofo italiano prefiere ver continuidad y desarrollo en estas dos etapas: «La llamada Kehre, o vuelta o giro, del pensamiento heideggeriano, que constituyó un problema central de la crítica hasta hace unos diez años, ya no se manifiesta como un abandono de las posiciones de Ser y tiempo, sino que se revela -como el mismo Heidegger la entiende- como una continuación y una profundización del discurso iniciado en aquella obra. El hecho de que, como se dice en la Carta sobre el humanismo, el pensamiento se mueva no en un plano en el cual está exclusivamente el hombre, sino en un plano en el cual está principalmente y ante todo el ser, expresa sencillamente el paso que va del análisis preparatorio de Ser y tiempo a la elaboración del problema del sentido del ser al que debía servir aquella preparación`». La diferencia entre el primer y el segundo Heidegger consiste, por tanto, en que en Sery Tiempo, como no sabe cómo contestar a la pregunta por el sentido del ser, que es la finalidad originaria esencial, se detiene a analizar la pregunta y en ella lo más importante que detecta es al que hace la pregunta: el hombre (Dasein). Con esto, la obra se convierte en una antropología existencial. El segundo Heidegger, por influencia de Nietzsche ${ }^{8}$, desplaza la atención desde el hombre al ser. En relación con el origen de la obra de arte y la verdad de la misma, considera que el sentido del ser es el poder (la voluntad de poder).

Las claves esenciales del primer Heidegger se mantienen, por tanto, en el segundo. Esta continuidad de pensamiento se ve reflejada en los temas que componen la filosofía de su segunda etapa, resumidos en los siguientes puntos?:

7 Vattimo, G., Introducción a Heidegger, Gedisa, Barcelona, 1995, p. 95.

8 Podemos hacernos una idea de la lectura que Heidegger hace de Nietzsche con el libro de José vidal Calatayud: Nietzsche contra Heidegger. Ontología estética, Madrid, Dynkinson, 2008. En él se defiende la tesis de que hay dos interpretaciones de Nietzsche por parte de Heidegger. La primera nos presenta un Nietzsche que es objeto de críticas por ser el último reducto de la metafísica occidental. Sirve para realizar el proceso de deconstrucción de la metafísica. Se trata de una lectura diacrónica, metafísica, de Nietzsche. La segunda interpretación es una lectura sincrónica, estética, de las ideas de Nietzsche, las cuales conforman el pensamiento de Heidegger. Este segundo Nietzsche que nos presenta Heidegger es el que opera en obras como «Tiempo y ser» y que inspira conceptos como Abgrund o lethe (ocultamiento).

9 Estos puntos están recogidos de la intervención de la profesora Teresa Oñate en el Seminario de Profesores e Investigadores de la UNED, con el títu- 
1. Crítica a la metafísica occidental como metafísica del fundamento y del sujeto. Es también una crítica a la metafísica nihilista que confunde el ser con el más general de los conceptos. La historia de la metafísica occidental es la historia del olvido del ser. El último tramo de esta historia de olvido pertenece a Hegel.

2. Exigencia de mantener abierta la diferencia ontológica entre ser y ente. Ello exige no proyectar lo Uno (Ser) en lo múltiple (ente). Ser y ente pertenecen a diferentes ámbitos.

3. Explicitación de la «vuelta» (Kehre). Aunque el ser, el tiempo y el hombre siguen siendo tema central de reflexión, ésta experimenta un giro, consistente en un retroceso a algo más originario: el hombre gravita ahora en torno al ser y al lenguaje, y no al contrario. Cuatro son los aspectos destacados de esta vuelta:

a) La radicalización ontológica del criticismo y del idealismo trascendental Kantiano: se pregunta por las condiciones de posibilidad de los fenómenos.

b) Ontologización del espacio y del tiempo del ser, entendido como lenguaje político.

c) La explicitación de la doctrina del eterno retorno nietzscheana como método del pensar hermenéutico, esto es, como método hermenéutico.

d) Concepción del lenguaje como la casa del ser: el lenguaje es el lugar donde puede manifestarse lo que llamamos «ser».

4. La doctrina ontológica del acontecer o acaecimiento apropiador (Ereignis) de la verdad como «aletheia». Esta doctrina metafísica desplaza la filosofía del espíritu de Hegel y propone que no sólo la obra de arte es el lugar de la verdad; ésta también acontece en la religión y en la fundación de Estados. Esto implica saltar de la metafísica de la historia del olvido del ser a una temporalidad y espacialidad que no son ya ni de la subjetividad del hombre ni tampoco son pensadas desde el ente como fugacidad o contingencia. Son pensadas, desde Sery tiempo, como tiempo y espacio vinculados, como tiempo propio que permanece mientras pasa. Así, Heidegger puede abordar la pregunta característica de su segunda época: la que concierne al misterio del devenir del ser. La doctrina ontológica del acaecimiento apropiador permite, mediante una modificación de las filosofías del arte, la religión y la política, saltar

lo «La esencia del legado del segundo Heidegger» (20-5-2009). Accesible en http://www.teleuned.com/teleuned2001/html/. 
a otro espacio y a otro tiempo.

5. Doctrina del misterio de la Tierra, referido a lo tapado, lo velado, lo oculto. Lo que aparece es la epifanía del misterio como tal. Esta epifanía altera en el lenguaje la predicación que relaciona sujeto y predicado. El pasado es rememorado en el presente para posibilitar el futuro de la diferencia. Los tres éxtasis de la temporalidad-pasado, presente y futuro- están enlazados por la diferencia. Pensar es sincronía y logos de la razón hermenéutica como condición de posibilidad de toda lingüisticidad.

6. La ontología estética de la percepción (aisthesis) de la experiencia noética del espacio-tiempo del lenguaje del ser.

7. Serenidad: dejar ser al darse del ser. Se trata de una receptividad trascendental activa que permite y abre el espacio-tiempo sincrónico desde donde se da la eternidad inmanente del misterio del devenir del ser.

\section{I.2. LO QUE CARACTERIZA AL PREFIJO «POST-»}

De acuerdo con Vattimo ${ }^{10}$, lo que la postmodernidad trata de pensar, en base al significado del prefijo «post-», es la actitud crítica que Nietzsche y Heidegger tuvieron para con la herencia del pensamiento moderno europeo $^{11}$. En el caso del primero, su actitud crítica reside en el planteamiento de la problemática del eterno retorno y en el anuncio del nihilismo consumado. La crítica de Heidegger se dirige a la metafísica, que hay que rebasar, y al humanismo. Sin embargo, estos filósofos no orientan su crítica hacia una superación de la modernidad, pues ello hubiese supuesto el permanecer atados a la lógica del desarrollo, propia del pensamiento que critican. Hablar de «superación» (con el sentido de la Aufhebung hegeliana) es hablar también del pensamiento como desarrollo progresivo de ideas, siendo las últimas superación de las anteriores en virtud de su retorno al origen-fundamento, que es recuperado y apropiado. Un pensamiento, el occidental, caracterizado por su búsqueda progresiva del fundamento, no puede ser criticado proponiendo un nuevo Grund, aún más verdadero que el anterior.

10 Vattimo, G., El fin de la modernidad, Gedisa, Barcelona, 1996. p. 9 y ss. 11 Vattimo, G., Las aventuras de la diferencia, op. cit., p. 5. Con Nietzsche y Heidegger cambia la noción misma del pensamiento y el «pensar» asume un nuevo significado. En Heidegger, concretamente, es la apelación a la diferencia lo que define este nuevo pensamiento. 
En efecto, si algo caracteriza a la modernidad es el ser un fenómeno intelectual que concibe la historia del pensamiento como una marcha progresiva hacia la «iluminación» (del pensamiento y la realidad, y a su ulterior identificación), entendida como un proceso de apropiación y reapropiación de los «fundamentos»-orígenes-, a los que continuamente tratan de retornar los diversos y sucesivos sistemas filosóficos ${ }^{12}$.

Nietszche y Heidegger pueden ser llamados filósofos de la postmodernidad porque no se doblegaron a la lógica del desarrollo ni a la idea de superación que dan forma al pensamiento moderno. Sus reflexiones nos enseñan que «el post de posmoderno indica una despedida de la moderni$\operatorname{dad}^{13}{ }^{\prime}$, despedida que no hay que entenderla en el sentido de superación, sino en el de abandono de sus planteamientos. La postmodernidad, pues, no es un momento ulterior respecto a la modernidad; es ruptura con la modernidad, lo cual hace que advirtamos una auténtica novedad en el cambio de las condiciones de existencia y pensamiento, pero a condición de disolver la categoría de lo «nuevo». Esta ruptura de la categoría de lo «nuevo», consecuencia de la disolución o ruptura de la unidad de la historia, tiene lugar en la actual sociedad de consumo, en la que la «novedad» ya no tiene nada de novedoso ${ }^{14}$. El mundo de la técnica adolece de un inmovilismo de fondo que disuelve la propia idea de progreso. Esta idea de progreso es fruto del proceso de secularización que se ha realizado en la modernidad: «La historia que, en la visión cristiana, aparecía como historia de la salvación, se convirtió primero en la busca de una condición de perfección intraterrena y luego, poco a poco, en la historia del progreso: pero el ideal del progreso es algo vacío y su valor final es el de realizar condiciones en que siempre sea posible un nuevo progreso. Y el progreso, privado del "hacia el dónde" en la secularización, llega a ser también la disolución del concepto mismo de progreso, que es lo que ocurre precisamente en la cultura entre el siglo XIX y el siglo $\mathrm{XX}^{15}$ ». El nexo entre modernidad, secularización y valor de lo nuevo queda patente 1) en el abandono de la

12 De hecho, Heidegger, junto con Nietszche, ambos considerados teóricos de la hermenéutica, advierte que uno de los rasgos más destacados de la conciencia moderna es la «enfermedad histórica», la cual está todavía por «superar». Cfr. Vattimo, G., Las aventuras de la diferencia, op. cit., p. 16.

13 Vattimo, El fin de la modernidad, op. cit., p. 10.

14 Ibíd., p. 13.

15 Ibíd., p. 15. 
visión sacra de la existencia en favor de la afirmación de lo profano, 2) en la fe en el progreso, al que se le da un valor en sí y se le considera un arma teórico-práctica con la que luchar contra la idea del fin de la historia y 3) en la afirmación de lo «nuevo» como valor fundamental, reflejo de la religiosa visión providencial de la historia ${ }^{16}$.

Desde la crítica a la modernidad, lo postmoderno anuncia, por un lado, la negación de las estructuras estables del ser y, por otro, la experiencia del «fin de la historia» ${ }^{17}$. La disolución de las estructuras estables del ser, que acontece en las filosofías de los siglos XIX y XX, obliga a entender el ser como evento. La eventualidad del ser, tal y como es planteada por Nietzsche y Heidegger, obliga a concebir la ontología como interpretación de nuestra condición o situación en la que el ser y el hombre se relacionan en un juego de proyección histórica. La postmodernidad es una edad postmetafísica en virtud de la destrucción de la ontología (de la metafísica occidental) llevada a cabo por los citados filósofos: el hombre y la realidad no pueden ser ya pensados en orden a estructuras estables que obligan al pensamiento a fundamentar la existencia. En consonancia con esta idea, hay que admitir que la experiencia postmoderna de la verdad es, probablemente, una experiencia estética y retórica, que nada tiene que ver con las emociones y sentimientos subjetivos. La experiencia de lo verdadero se refiere a «la imposibilidad de reducir el hecho de la verdad al puro y simple reconocimiento del 'sentido común'» ${ }^{18}$.

Respecto al «fin de la historia», su significado remite a un nuevo modo de vivir bajo condiciones de no historicidad o posthistoricidad: se disuelve la idea de una historia como proceso unitario tendente al progreso. Dice Vattimo: «Existe una filosofía del terrorismo, y es aquella que lleva a sus últimas consecuencias la idea de que la historia humana tiene una norma absoluta, un valor final que realizan $\rangle^{19}$. Hay que reconocer que la historia no tiene sentido «absoluto». El sentido de la historia sólo es poseído por quien la hace. La «disolución» de la historia es el rasgo que más diferencia a la historia contemporánea de la historia moderna. La historia contemporánea es la historia en una época en la que se ha producido una deshis-

16 Ibíd., p. 92 y s.

17 Ibíd., p. 12.

18 Ibíd., p. 19.

19 Vattimo, G., Más allá del sujeto. Nietzssche, Heideggeer y la hermenéutica, Paidós, Barcelona, 1992 , op. cit., p. 16. 
torización de la experiencia debido al influjo de los mass media, los cuales han provocado que todo quede reducido al plano de la contemporaneidad y de la simultaneidad ${ }^{20}$.

Por estas razones, concluye Vattimo, la postmodernidad debe ser reconocida como «campo de posibilidades» para el ser humano, y no «como el infierno de la negación de lo humano» $»^{21}$. A su parecer, esto se comprende mejor si atendemos a la diferencia entre lo que Heidegger quiere expresar con el término «Verwindung» y lo que se expresa con el término «Überwindung», puesto que sirve para definir el post de la postmodernidad filosófica. Pero hay que advertir con Vattimo que lo señalado por el primer término, utilizado raramente por Heidegger, fue expresado por primera vez por Nietzsche, quien nunca lo empleó. Por este motivo, éste último puede ser considerado el padre de la filosofía postmoderna.

«Verwindung es la palabra que Heidegger usa, por lo demás bastante raramente (en una página de Holzwehe, en un ensayo de Vorträge und Aufsätže y sobre todo en el primero de los ensayos de Identität und Differenz), para designar algo que es análogo a la Überwindung, la superación o rebasamiento pero que se distingue de ésta porque no tiene nada de la Aufhebung dialéctica ni del 'dejar atrás' que caracteriza la relación con un pasado que ya no tiene nada que decirnos ${ }^{22} \gg$. El concepto heideggeriano de Verwindung recoge lo que, según Vattimo ${ }^{23}$, Nietzsche busca con la expresión «filosofía de la mañana», en la cual reside la esencia de la postmodernidad filosófica. La filosofía de la mañana es el pensamiento «no orientado ya hacia el origen o el fundamento, sino orientado a lo próximo ${ }^{24} \gg$. Se trata de un pensamiento del error en cuanto examina la evolución de las falsas construcciones metafísicas o del «ser» de la «realidad». Consiste esencialmente en una crítica a la función que la modernidad otorgó al pensamiento: el remontarse al fundamento para encontrar el valor del nuevo ser que confiera sentido al devenir histórico. Por ello, Vervindung describe un referirse al pasado de la metafísica y, consecuentemente, a la modernidad como resultado final de ésta y de la moral platónico-cristiana, en el que ni se acepten sin más sus errores ni sean éstos criticados al objeto de superarlos, lo cual

20 Vattimo, G., El fin de la modernidad, op. cit., p. 17.

21 Ibíd., p. 19.

22 Ibíd., p. 145.

23 Ibíd., p. 151.

24 Ibíd., p. 149. 
supondría una continuación de los mismos. Así, Verwindung, al igual que Überwindung, indica la «superación» de la metafísica, pero en el sentido, no de una Aufhebung, sino en el de un rebasamiento que acepta y profundiza en el dolor y la resignación. Vattimo: «Para Heidegger, la posibilidad de un cambio que nos conduzca hacia un Ereignis más principal -es decir, fuera de la metafísica, más allá de la metafísica- está relacionada con una Verwindung de la metafísica (...), la metafísica es algo que permanece en nosotros como los rastros de una enfermedad, o como un dolor al que uno se resigna o también, podríamos decir, aprovechando la polivalencia del término 'remitirse', que la metafísica es algo de lo que uno se remite, se recobra, algo a lo que uno se remite, algo que se remite (se envía). Además de todos estos significados, está también el de dis-torsión que se puede interpretar, por lo demás, en el significado de la convalecencia y la resignación: no se acepta la metafísica pura y simplemente, así como uno no se entrega sin reservas al Ge-Stell como sistema de la imposición tecnológica; se puede vivir la metafísica y el Ge-Stell como una Chance, como la posibilidad de un cambio en virtud del cual metafísica y Ge-Stell se truecan en una dirección que no es la prevista por su esencia propia pero que sin embargo tiene conexión con ella» ${ }^{25}$. Todos estos significados de Verwindung expresan la posición de Heidegger respecto a la función del pensamiento en el momento del fin de la filosofía en su forma metafísica: el errar incierto de la metafísica, por cuanto que rememora en una actitud ajena a la superación crítica y a la aceptación que repite sin más ${ }^{26}$.

A partir de esto se puede establecer una relación entre Verwindung y Andenken (rememoración, pensamiento rememorante): el concepto heideggeriano de Andenken posibilita que el pensamiento postmetafísico sea definido como rememoración. El error de la metafísica ha consistido en el olvido del ser, pero este error no se debe al hombre sino que se haya inserto en el ser mismo por el hecho de que el ser nunca se da por entero a su

25 Ibíd., p. 152.

26 En opinión de Vattimo, la Verwindung de la metafísica se plantea ya en Ser y tiempo: «Con la exposición -que tampoco puede interpretarse como la pura y simple postura de un pensador- del problema ser-tiempo, comienza la Verwindung de la metafísica: el ser se da ahora, según ya está anunciado en el nihilismo de Nietzsche, como algo que se desvanece y perece, no como algo que está (y esto desde Ser y tiempo) sino como algo que nace y muere». Cfr, Ibíd., p. 56. 
presencia ${ }^{27}$. En consecuencia, la rememoración consiste en un remontarse infinitamente a la historia del pensamiento para darnos cuenta de que no vamos a ninguna parte nueva sino diferente, y en un recuerdo permanente del ser como algo de lo que ya nos despedimos ${ }^{28}$.

Con esta introducción se ha puesto en contexto el porqué del carácter eventual atribuido al ser por parte de Vattimo. Abordamos, a continuación, el estudio de esta eventualidad preconizada, en mayor medida, en el ulterior pensamiento de Heidegger, y para ello creemos conveniente analizar los conceptos heideggerianos de Ereignis -que el autor italiano traduce por «evento» ${ }^{29}$ y $G e-S t e l \beta^{0}$, puesto que así como el primero anuncia una nueva concepción de lo que es el ser, el segundo señala el momento epocal que la hace posible.

La filosofía del Ereignis aparece en varias obras de Heidegger (por primera vez, en un comentario a Hölderlin de 1934-35), aunque por razones metodológicas he optado por el estudio de Tiempo y ser $^{31}$, que incluye la

27 Este es el otro significado que Vattimo da a la Kehre del pensamiento de Heidegger, además del de paso desde un plano en el que se está sólo el Dasein a un plano presidido por el ser.

28 Esta idea permite definir la filosofía de Heidegger como una hermenéutica ontológica de la diferencia.

29 «Evento» es la palabra que traduce Ereignis en toda la obra de Vattimo. La versión española de Zur Sache des Denkens traduce Ereignis por «acaecimiento apropiador». La profesora traduce Das Ereignis por «El Acontecer-(des)Apropiador». Según sus propias palabras: «Yo traduzco «Das Ereignis» por «El Acontecer-(des) Apropiador», respetando, por un lado, el sentido infinitivo--verbal de la expresión sustantivada y reflejando también que la matriz de «lo propio» (Eigen) del «Das Ereignis» incluye para Heidegger un simultáneo expropiar (Ent-eig-nen) o des-apropiar estructural; ya que se trata de un apropiar que implica una co-pertenencia (entre Tiempo y Ser; o entre Pensar y Ser) que instaura, a la vez, cuando acontece, la recíproca alteridad constituyente de la esencia del otro para cada uno; del ser de cada uno con y para el otro y por el otro. Las traducciones que vierten Das Ereignis por «evento» introducen un matiz contingente, casi de «suceso» «eventualista» del todo inapropiado en el plano del Acontecer necesario y posibilitante del Ser (Seyn) - en infinitivo verbal—- que en nada resulta acorde con la modalidad de la Diferencia Ontológica que distingue el ámbito de lo ser (necesario posibilitante) y el de lo ente (contingente posibilitado). Cfr. Oñate, T., «Heidegger, hó Skoteinós [El obscuro]. La ontología Estética del Espacio-Tiempo tras la Kehre», Estudio Preliminar a El segundo Heidegger: Ecología. Arte.Teología. Dykinson, Madrid, 2012.

30 Cfr., Berciano, M., «Heidegger, Vattimo y la deconstrucción», Anuario Filosófico, 1993, p. 17.

31 Esta obra traduce, como se ha dicho en la primera nota, a la original Zur Sache des 
conferencia de título homónimo en la que lo concebido por dicho vocablo queda más dilucidado. Respecto al término Ge-Stell, también empleado por el filósofo alemán ${ }^{32}$, he preferido ceñirme al tratamiento que Vattimo hace del mismo en algunas de sus obras. La comprensión de ambos conceptos y de su relación es importante para abordar un pensamiento postmetafísico, que, según Vattimo, es el único que puede dar respuesta a la vieja cuestión de la metafísica sobre el sentido del ser.

\section{REPENSAR EL SER CON LA CONFERENCIA «TIEMPO Y SER》}

El objetivo de la conferencia «Tiempo y ser» es la nueva indagación sobre la experiencia humana del ser:

«El intento de pensar el ser sin lo ente se torna necesario, pues en caso contrario no subsiste ya, a mi parecer, posibilidad alguna de traer con propiedad a la mirada el ser de aquello que hoy es en todo el derredor del globo terráqueo, y menos aún de determinar suficientemente la relación del hombre con aquello que hasta ahora llamamos 'ser'» ${ }^{33}$.

Estas palabras del comienzo de la conferencia nos sugieren el propósito del segundo Heidegger, el de la Kehre. El lenguaje entificador, cosificador o presentificador empleado por la tradición metafísica resulta insuficiente para pensar el ser. Ahora, se trata de «pensar el ser sin lo ente». La pretensión es ver en qué medida es posible una comprensión no metafísica del ser, pues el ser ya no es «obvio», ni es pensado como «objeto»; ni siquiera su relación con el pensamiento se puede definir como la relación de un objeto con un sujeto. El «Protocolo» ofrece una aclaración de este giro: «Pensar el ser sin lo ente" quiere decir, por tanto, no que al ser le fuese inesencial la relación a lo ente, que pudiera prescindirse de esta relación; quiere decir más bien no pensar al ser al modo de la metafísica ${ }^{34} \gg$. El ser es con relación a lo ente aquello que muestra, hace visible, sin mostrarse a sí

Denkens (El asunto del pensar), M. Niemeyer, Tübingen, 1969, que contiene la conferencia «Tiempo y ser», cuyo título da nombre a la edición española que manejamos.

32 Heidegger habla de él por primera vez en una conferencia de 1949, de título homónimo. Posteriormente, en 1954, expone ampliamente su concepto en su ensayo Die Frage nach der Technik, uno de los que integra la obra Vorträge und Aufsätze (trad. española: Conferencias y artículos, Ediciones del Serbal, Barcelona, 1994). También lo trata en la obra Identität und Differenæ, 1957 (trad. española: Identidad y Diferencia, Anthropos, colección Siglo Clave, Barcelona, (2013)

33 «Tiempo y ser», en Heidegger, M., Tiempo y ser, Tecnos, Madrid, 1999, p.20.

34 «Protocolo de un seminario sobre "Tiempo y ser"», en Tiempo y ser, op. cit., p. 53. 
mismo. Así, puede decirse que, respecto a las cosas, el ser se muestra como la negatividad, como la nada del ente.

El pensar occidental europeo siempre ha concebido el ser fundamentalmente como lo que está presente, esto es, como presencia determinada por el tiempo. Esto ha supuesto el olvido del ser, y una fijación exclusiva en los entes. Sin embargo, si se analiza el lenguaje natural, resulta obvio que ni del ser ni del tiempo se puede decir que son. El ser no es una cosa real y concreta, no se puede decir que «es», como si estuviera circunscrito en un tiempo presente. Por tanto, el ser no es una realidad temporal, algo determinado como presencia por el tiempo. Se impone, consiguientemente, repensar una nueva relación entre el ser y el tiempo. Ambos se determinan recíprocamente, pero teniendo en cuenta que el ser no se deja apelar como algo temporal, ni el tiempo como ente. La tarea del pensar consiste en meditar sobre la «cosa»-asunto o cuestión- del ser y del tiempo y de la relación interna de ambas cosas.

Cuando el pensamiento se dirige cautelosamente hacia la cosa del ser y el tiempo, constata que, tratándose del ser, no se puede emplear la forma verbal «es» para expresar la manera de acontecer el ser y el tiempo. En su lugar, hay que emplear la forma «se da». Es necesario cambiar el uso lingüístico: el ser no es, sino que «se da»; el tiempo no es, sino que «se da». Pero el decir de «Se da ser» $\mathrm{y}$ «Se da tiempo» no hay que entenderlos como enunciados $^{35}$. La expresión «Se da» confiere el movimiento decisivo a la conferencia. Hay que notar, según se aclara en el Protocolo, que Es gibt expresa también el «hay», con lo cual la referencia al hombre queda patente ${ }^{36}$. Ahora es fundamental tratar de divisar el Se o Ello que da ser y tiempo.

El estar presente se muestra como un dejar que se esté presente. El ser no es lo que está presente, sino lo que permite que algo esté presente. El dejar-estar-presente quiere decir desocultar, traer a lo abierto. Esto supone la entrada en el juego de la donación: en tanto que el ser se da, permite dejar-estar-presente, es decir, da dicho estar presente: el ser. «El ser Se da como el desocultar del estar presente ${ }^{37}$. No se trata de que el ser «dé» al ente como realidad presente; por el contrario, es el ser mismo el que se da. Esta donación del ser no ha de ser entendida en sentido causal, según la

35 Ibíd., p. 60.

36 Ibíd. p. 58.

37 «Tiempo y ser», p. 25. 
explicación onto-teológica de la metafísica tradicional. La cuestión última no es el qué de los entes, sino el sentido del ser. Por ello, «lo afectado por este dejar no es ya lo que está presente, sino el estar presente mismo ${ }^{38}{ }_{\eta}$. El ser no es algo que está ahí, concebido como objeto que causa la existencia y el conocimiento de la misma. La pregunta por el sentido del ser se queda en la pregunta misma porque el ser como respuesta no puede ser entendido como referente objetual.

La caracterización del ser como lo que es o está presente, propio del pensar occidental desde su inicio en los griegos, encuentra su máxima expresión en el contexto moderno del desarrollo técnico e industrial: «el ser como estar presente en el sentido de lo que cuenta como un stock de mercancías ${ }^{39}$ \%. Aquí, el estar presente es entendido como el estar delante y el estar a mano de lo ente, de acuerdo con el planteamiento de Ser y tiempo ${ }^{40}$. No obstante, este estar presente ha sufrido varias transformaciones a lo largo de la historia de la metafísica. En este sentido, se puede hablar de una historia del ser, en cuyo desarrollo el ser ha ido aconteciendo de diferentes modos, según la manera de darse. Y es precisamente en esta historia donde mejor se capta el «Se da» del ser, aunque este «Se da» haya pasado inadvertido. Incluso, en el alba del desocultamiento del ser, en el instante de ser pensado - «el ser, pues, es», reza la sentencia de Parménides-, el «Se da» no ha sido atendido por el pensamiento. Esto se explica por el hecho de que el «Se da» del ser se retira a favor del don; don que va a ser conceptualizado como ser en relación al ente. Pero hay más: la historia del ser implica el destino del ser: «Lo histórico de la historia del ser se determina desde lo destinable de un destinar ${ }^{41} \gg$. Las transformaciones del ser a lo largo de las distintas épocas históricas adquieren la forma de destinaciones diversas del ser, en las cuales el ser se retiene a sí mismo para que el don pueda ser

38 «Protocolo», p. 56 y s.

39 «Tiempo y ser», p. 26.

40 A este respecto, Vattimo critica a Heidegger la concepción de la instrumentalidad como ser de las cosas desarrollada en Ser y tiempo, y a la que subyace la idea de que el mundo es, en tanto que producto técnico, producto del hombre: «Desde este punto de vista, la concepción desarrollada en Sery tiempo de la instrumentalidad como ser de las cosas se revela también ella como una concepción que pertenece a la época de la metafísica y de la total reducción del mundo al sujeto», Introducción a Heidegger, Gedisa, Barcelona, 1995 , p. 84.

41 «Tiempo y ser», p. 28. 
percibido. En cada época, el Se o Ello que destina, y las destinaciones del ser, han quedado contenidas en la manifestación de sí mismas. Lo peculiar del ser no es ningún tipo de ser, sino que «se muestra en el Se da y en el dar de éste como destinar $\left.{ }^{42}\right\rangle$.

Como reacción a esta situación histórica de olvido del ser, se impone el desmantelamiento de los encubrimientos del ser. Gracias a esta «destrucción», el pensar puede dirigir una mirada precursora a lo que se desvela como el destino-del-ser, un destino que se representa como historia, y ésta como acontecer.

El discurso del estar presente reclama la permanencia. Pero en el permanecer del dejar estar presente debemos notar el hecho de aguardar y seguir aguardando. De ahí que el hombre sea aquél a quien le atañe lo que está presente y percibe lo que aparece en el dejar estar presente porque la presencia es «el constante seguir aguardando que atañe al hombre, que lo alcanza y que le es ofrendado ${ }^{43}$ ). Sin embargo, al hombre también le atañe el estar ausente, lo no-presente, lo cual implica que el estar presente se extiende en el pasado, en el ad-venir-nos o en el por-venir. El ser, como vemos, no es meramente lo presente: «no todo estar presente es, cosa extraña, necesariamente el tiempo presente ${ }^{44}$ ». El presente es aportado por la relación entre pasado y futuro. Pasado, presente y futuro están en un recíproco ofrendarse: «Advenir como todavía no presente, extiende y aporta simultáneamente lo ya no presente, el pasado, y a la inversa éste, el pasado, se extiende hasta alcanzar el futuro. La relación de cambio de ambos extiende y aporta simultáneamente al presente ${ }^{45}$ ». El tiempo no puede entenderse como una simple sucesión de ahoras. El recíproco-ofrendar-se de porvenir, pasado y presente esclarece lo abierto, nombrado por el espacio-tiempo. Este ofrendarse es pre-espacial y, por ello, puede dar espacio. El despliegue original del tiempo es visualizado como extensión o regalía, un despliegue que tiene una función de esclarecimiento. Estamos, por tanto, ante un tiempo más «mundano» que humano ${ }^{46}$. El tiempo auténtico es, en consecuencia, tetradimensional: a las tres dimensiones del recíproco ofrendarse de porvenir, pasado y presente (la triple regalía del tiempo) se

42 Ibíd., p. 29.

43 Ibíd., p. 32.

44 Ibíd., p. 32.

45 Ibíd., p. 33.

46 Cfr. Introducción Tiempo y ser, op. cit., p. 15. 
añade la cuarta dimensión de «la regalía que todo lo determina», constituida como espacio que posibilita el donde. La unidad del tiempo auténtico se muestra como cercanidad (Naheit), la cual «acerca mutuamente porvenir, pasado y presente, en la medida en que los aleja ${ }^{47}$ ». Gracias a ello, mantiene abierto el pasado, lo sido, y recusa su porvenir como presente. Se trata de una cercanía acercante que tiene el carácter de la recusación y de la retención. El tiempo no es, sino que se da. Y ese dar, que da tiempo, es determinado desde la recusante-retinente cercanía, procurando lo abierto del espacio-tiempo y preservando lo que permanece recusado en el pasado, el cual permanece, a su vez, retenido en el futuro. El dar del darse del tiempo es regalía esclarecedora-ocultadora.

Hay que aclarar que el tiempo no se da sin el hombre, sin ser ninguno producto del otro. El tiempo se da, y ese dar se da como ofrendar o extensión esclarecedora del espacio-tiempo. No obstante, el hombre sólo puede ser como tal si «está en el interior de la triple regalía y ante la recusante-retinente cercanía que lo determina» ${ }^{48}$.

Si el dar del «Se da el tiempo» se muestra como regalía que esclarece la región esclarecedora, el dar del «Se da el ser» se muestra como destinar y como destino de presencia en sus diferentes transformaciones epocales. He aquí la relación entre el tiempo y el ser: el «Se» o «Ello» que da el ser -el estar presente- queda esclarecido por lo abierto del tiempo auténtico. Cuando decimos que Se da el ser, aparece el tiempo auténtico como el Se o ello, de ahí que el destinar del ser repose en la regalía del tiempo. Pero el Se o Ello que da el ser no debe ser entendido como sustrato de lo que está presente, a modo de causa de la existencia de los entes, pues el estar presente implica un estar ausente. El ser acontece epocalmente como un darse que se oculta a lo dado. Este ocultarse del ser es un sustraerse epocal (epochê), consistente en un hacer sitio a los entes en sentido espacial, pero también, y sobretodo, en sentido temporal: «El ser se retrae y deja que el ente se despliegue en el tiempo. La historia es posible porque el ser siempre está por venir. Las épocas de la historia se han hecho posibles gracias al carácter epocal del ser. Hay auténticamente historia, es decir, posibilidad, futuro, etc., sólo porque él se retrae ${ }^{49} \gg$. Sin duda, esta forma de pensar

47 «Tiempo y ser», p. 35.

48 Ibíd., p. 36.

49 Vattimo, G., Poesía y ontología, Universitat de Valencia, Valencia, 1993. p. 28. 
el ser y el tiempo escapa a los esquemas enunciativos o proposicionales del lenguaje. Por esta razón, se introduce un nuevo «concepto»: el acaecimiento apropiador (das Ereignis).

$\mathrm{El}$ acaecimiento apropiador es la idea o experiencia con la que pensar o traer a la mirada al ser mismo. El ser no es lo que está presente, sino un Se da que supone, al mismo tiempo, un contener y un retirar. Ser como acaecimiento apropiador sin que éste sea o se dé, pues se expropia de sí mismo. De este modo, lo que nombra el acaecimiento no puede ser representado: «el ser se demuestra como el don, concedido en verdad mediante la regalía del tiempo, del destino de la presencia. El don, la donación del estar presente, es propiedad del apropiar. El ser desaparece en el acaecimiento apropiador ${ }^{50} \%$. Lo propio del ser y del tiempo, lo que determina a ambos, es su recíproca copertenencia, y ésta es llamada acaecimiento apropiador. Pero el acaecimiento apropiador no puede ser establecido ni como ser ni como tiempo ${ }^{51}$. Con esto, el ser deja de ser entendido como fundamento y se convierte en una experiencia del ser como evento. El acaecimiento apropiador no puede ser entendido a modo de preparación de un fundamento cada vez más originario.

Según Vattimo, la introducción del Ereignis es esencial para explicar la relación entre el ser y el hombre: «En la medida en que tiempo y ser sólo se dan en el apropiar, a éste último pertenece lo peculiar que trae al hombre a lo que él tiene de propio como aquel que se percata del ser, mientras persiste en el interior del tiempo auténtico. Así apropiado pertenece el hombre al acaecimiento apropiador». El reducir el ahí del Dasein -la espacialidad del estar humano- a la temporalidad, según Sery tiempo, es insostenible. $\mathrm{Ni}$ el hombre es sin el ser ni el ser sin el hombre, pero «el ser sólo puede concebirse como aquello que se apropia del hombre entregándose a él'57》. $\mathrm{El}$ acontecer es el ser mismo, por lo que solo puede acontecer en su relación con el hombre. Ser y hombre no son realidades en sí que posteriormente entran en relación. El ser se da como evento que ilumina la apertura histórica en la que se encuentra el Dasein. Esta iluminación acontece en el hombre disponiendo, a su vez, de él. En consecuencia, por su naturaleza eventual, «el ser nunca es otra cosa que su modo de darse histórico a los

50 Ibíd., p. 41.

51 «Protocolo», p. 63.

52 Cfr. Vattimo, G., Introducción a Heidegger, op. cit., p. 100 
hombres de una determinada época, quienes están determinados por este darse en su esencia misma, entendida como el proyecto que los constitu$\mathrm{ye}^{53}$ 》. El hombre «es» un estar siempre lanzado en un modo histórico de aparecer el ser en sus distintas aperturas. Al ser estas aperturas históricas, el acaecimiento apropiador implica una recíproca apropiación-expropiación de hombre y ser. El hombre no sólo se encuentra con las aperturas históricas -comprensiones del ser-, sino que también las determina. Hombre, historia y ser están entrelazados en el acaecimiento apropiador.

La estructura del acaecimiento apropiador es explicada también según el modelo de la relación del hombre con el lenguaje ${ }^{54}$. El hombre dispone del lenguaje, pero también el lenguaje dispone de él, se apropia de él, porque limita su posible campo de experiencia del mundo. El lenguaje es el lugar y el modo en que se nos manifiestan las cosas del mundo. En el hablar acontece la apertura del mundo. Por ello, «el lenguaje es la sede del evento del $\left.\operatorname{ser}^{55}\right\rangle$.

\section{II.1. EL FINAL DE LA FILOSOFÍA Y LA TAREA DEL PENSAR}

A la pregunta ¿qué es la metafísica, según Heidegger?, podemos responder con estas palabras del Protocolo: «La metafísica es la historia de las acuñaciones del ser, esto es, mirado desde el acaecimiento apropiador, la historia del retirarse del destinarse a favor de las destinaciones dadas en el destinar de un dejar en cada caso el estar presente de lo que está presente. La metafísica es olvido del ser, y esto es la historia del ocultamiento y de la retirada de aquello que da ser. La entrada del pensar en el acaecimiento apropiador equivale así al final de esta historia de la retirada. El olvido del ser se «cancela» con el desvelarse en el acaecimiento apropiador ${ }^{56}{ }^{6}$. En la historia de la metafísica se puede vislumbrar algunas etapas fundamentales ${ }^{57}$. Partiendo de Parménides, quien concibe la verdad como «aletheia», Platón reduce el ser a idea, esto es: lo verdadero es la idea, y la idea es concebida como el ente visible al intelecto (el ente en cuanto inteligible). De este modo, la verdad es revelación, importando únicamente el recto conoci-

53 Ibíd., p. 102.

54 Ibíd., p. 113 y ss.

55 Ibíd. , p. 115.

56 «Protocolo», en Martin Heidegger, Tiempo y ser, p. 61 y ss.

57 Vattimo, G., Introducción a Heidegger, op. cit., p. 82 y ss. 
miento de lo que se revela. Más tarde, Aristóteles concebirá el ser en dos sentidos: como esencia (éidos) y como sustancia (ousía). En tanto existencia efectiva, la sustancia es el ser en acto (energéia). Esta identificación aristotélica del verdadero ser con lo que está efectivamente presente dominará toda la edad media bajo el concepto de actualitas, actualidad atribuida en sentido propio a Dios, cuya presencia efectiva es eterna. Así, al carácter de presencia efectiva del ser se le adhiere la capacidad de fundación y de casualidad. En la época moderna, Descartes extrae las consecuencias de las concepciones platónica y aristotélica del ser e identifica el ser con la certeza: sólo es real (es ente) lo que es cierto (lo que representa una idea clara y distinta). «Lo que constituye la realidad de la cosa, su ser, es precisamente la certeza indudable que el sujeto tiene de ella y que puede adquirir con la aplicación rigurosa del método ${ }^{58}$ ». De modo que la palabra «sujeto» sufre un proceso de transformación y pasa a designar directamente el yo del hombre: «ya no es más la sustancia de un ente cualquiera (sustancia, substantia, tiene en latín un significado equivalente), sino que significa exclusivamente el yo del hombre; con esta transformación (que no es sólo una cuestión de palabras y de modos de pensar), el fundamento absoluto e indudable de la realidad es ahora el yo del hombre, ante el cual se debe legitimar el ser de las cosas que es reconocido como ser sólo en la medida que es cierto ${ }^{59}$ ». La correlación de la noción de «objetividad» a la noción de «sujeto» tiene su máxima expresión en la ciencia y técnica modernas: el «mundo objetivo» es producto del hombre-sujeto. Esto no es más que la reducción del ser a la voluntad del sujeto, en la que el yo es concebido como voluntad de reducción de la totalidad del ente a sí mismo. Es la concepción nietszcheana del ser como voluntad de poder.

La retirada emprendida por la metafísica al olvidarse del ser en favor de la atención a los entes se muestra como ocultamiento. Pero este ocultamiento deja de ocultarse en el acaecimiento apropiador. Con la entrada del pensar en el Ereignis, la historia del ser como lo que hay que pensar ha llegado a su fin. Lo que hay que pensar ahora es el modo en que se produce el desocultamiento, entendido como expropiación. De este modo, la concepción del ser como acaecimiento apropiador supone la desaparición del ser como ser, metafísicamente hablando.

58 Ibíd., p. 83.

59 Ibíd., p. 84. 
Según Heidegger, la metafísica concluye o acaba en el pensamiento de Nietzsche porque éste se presenta como el primer nihilista verdadero, y la esencia de la metafísica no es otra que el nihilismo. Interpretando la concepción nietzscheana del ser del ente como «voluntad de poder»-Heidegger habla de «voluntad de voluntad»-, refiriéndose al hecho de que la voluntad está sola, sin posibilidad de tender más allá de sí misma. Al término de la metafísica, el ser se caracteriza por la total falta de fundación. El hombre, al no ser otra cosa que proyecto lanzado, abre el horizonte de fundamentación del mundo. Pero el hombre es fundamento (Grund) únicamente como Abgrund, como ausencia de fundamento o abismo sin fondo ${ }^{60}$.

Al final de la conferencia «Tiempo y ser» se dice: «Pensar el ser sin lo ente quiere decir: pensar el ser sin referencia a la metafísica» ${ }^{61}$. Comprender el ser como Ereignis es pensar el ser de un modo distinto a como lo ha hecho tradicionalmente la filosofía occidental, esto es, reduciéndolo a ente. Por esta razón, este nuevo modo de pensar el ser supone el final de la metafísica, pues el ser ya no puede ser entendido como fundamento (Grund). Entender el ser como fundamento es reducirlo a aquello que está presente como causa óntica de lo real. Sin embargo, ya hemos visto que concebir el ser como acaecimiento apropiador nos conduce a una ontología de carácter dinámico y procesual ${ }^{62}$.

Pero este final de la metafísica es también el final de la Filosofía como desarrollo histórico del platonismo. Este final se refiere al «lugar en el que se reúne la totalidad de su historia en su posibilidad límite ${ }^{63}$ ». Según esto, la filosofía, como metafísica, se ha desarrollado en cada época de acuerdo a su propia necesidad, pero ya ha agotado sus posibilidades de comprensión de la realidad. Sencillamente, asistimos al acabamiento de la filosofía (aquella que es expresión del platonismo), acabamiento que hay que entender como desarrollo último, no como fin. El último coletazo es el desarrollo de las ciencias, dirigidas por una nueva ciencia fundamental: la Cibernética. El rasgo más importante de la ciencia es su carácter técnico:

60 Ibíd., pp. 79 y ss.

61 Tiempo y ser, op. cit., p. 44.

62 Cfr. Introducción a Tiempo y ser, op. cit., p. 15.

63 Martin Heidegger, «El final de la filosofía y la tarea del pensar», en Tiempo y Ser, op. cit., p. 78. 
reduce el ser a presencia, a dato empírico, y la verdad a eficacia ${ }^{64}$.

Si el final de la Filosofía se ha mostrado como el triunfo del método científico técnico, expresión de la metafísica de la presencia, ¿cuál es la tarea que le queda todavía reservada al pensar? Preguntarse por la tarea del pensar es hacerlo por la «cosa» (Sache) del pensamiento. Este intento por abordar la cosa del pensamiento fue acometido recientemente por Hegel y Husserl («a las cosas mismas») $)^{65}$. Sin embargo, ambos erraron en su planteamiento: el método con el que pretendían abordar la cosa del pensamiento acabó convirtiéndose en la cosa misma. Por esta razón, «desde el punto de vista de Hegel y Husserl -y no sólo para ellos- la «cosa» de la Filosofía es la subjetividad». Y la subjetividad es aquello que funda la «cosa», bien como saber absoluto, bien como evidencia definitivamente válida.

Sin embargo, queda todavía algo por pensar en la «cosa» de la Filosofía. Y ello sólo es posible gracias a la Lichtung ${ }^{66}$, lo abierto libre que hace posible que algo aparezca y se muestre, lo abierto para lo presente y ausente. Pues «la apertura es la única que ofrece a un dar y recibir, a una evidencia, la libertad en la que puede permanecer y tiene que moverse». La Lichtung es lo que impera en el ser y la presencia, aun así no ha sido pensado en la Filosofía, pero sí pensado en sus comienzos, en el Poema de Parménides. En él se nombra la aletheia, el no-ocultamiento, que ha de ser entendido como «la Lichtung que permite al Ser y al pensar el estar presente el uno en y para el otro» ${ }^{6}$. La Lichtung es el lugar en el que es posible el acuerdo entre Ser y pensar, por lo que la verdad es un elemento de ella. La verdad acontece en el libre juego del ser y el pensar del hombre, no es algo que esté ya dado en la presencia de lo «real», del mismo modo que el ser acaece apropiadoramente como relación con el hombre. De ahí que «sólo se conoce y piensa lo que posibilita la «aletheia como Lichtung, no lo que es ella en cuanto tal» ${ }^{68}$. La Lichtung es, pues, inseparable de la modalidad de la posibilidad y de la ausencia, pues es un espacio para el darse de la luz y la obscuridad. Que lo posible y la ausencia son, constituye el legado esencial

64 Un desarrollo de esta idea se encuentra en Jean Françoise Lyotard: La condición postmoderna; Madrid, Catedra, 1994.

65 Martin Heidegger, «El final de la filosofía y la tarea del pensan», en Tiempo y Ser, op. cit., p. 82 y ss.

66 Ibíd. p. 85 y ss.

67 Ibíd., p. 88 y s.

68 Ibíd., p. 91. 
del pensamiento de Heidegger.

En un momento en el que para el conocimiento se exigen pruebas eficaces, se impone como tarea del pensar: abandonar el pensar anterior y determinar lo que es la «cosa» del pensar, la cual escapa a toda demostración. Pero, ¿’en qué medida es posible acometer esta empresa? La respuesta la encontramos en la Introducción a Heidegger de Vattimo: concibiendo el pensamiento como hermenéutica ${ }^{69}$. La hermenéutica es la escucha del lenguaje, y en el lenguaje es donde el ser se manifiesta como acaecimiento apropiador. Esto quiere decir que el ser de las cosas y del hombre mismo acontece eventualmente en el lenguaje. Pero hay más: al ser la existencia constitutivamente relación con el ser, la hermenéutica o interpretación es la existencia misma en su dimensión más auténtica. La hermenéutica, en tanto que escucha e interpretación de la palabra, es atención a la existencia como evento del ser.

$\mathrm{El}$ «Protocolo» a la conferencia «Tiempo y Sen» también alude a la pertenencia recíproca de la relación entre ser y pensar y la cuestión del $\operatorname{ser}^{70}$. La relación de ser y pensar es la relación de ser y hombre: el pensar, el rasgo característico del hombre, pertenece esencialmente a la apertura del ser. Según ya hemos dicho, el pensar es un interpretar, y lo que piensa es la relación de ser y pensar y la cuestión del ser en general.

Respecto a la cuestión del ser en general, Vattimo ${ }^{71}$ señala dos lecturas o interpretaciones posibles de Heidegger:

1) La interpretación que acentúa el término «ser» (línea religiosa u onto-teo-lógica): el pensador preconiza una vuelta al ser.

2) La interpretación que pone el acento en el término «ocaso»: el pensador cree que la metafísica o historia del ser ha terminado porque ya nada queda del ser.

Ambas lecturas resultarían de la actitud del filósofo alemán en relación a la historia de la metafísica. No obstante, la Metaphysik. como Geschichte des Seins no es un desarrollo dialéctico.

Vattimo piensa que la escuela heideggeriana (la hermenéutica de Gadamer, por ej.) ha caído en el error de sostener la primera de las inter-

69 Op. cit., p. 120 y ss.

70 Op. cit., p. 54.

71 Ibíd., p. 48. 
pretaciones, llegando a pensar, incluso, que Heidegger concebía el ser en términos de fundamento. Esto a pesar de que en la conferencia «Tiempo y ser» se dice que se debe olvidar el ser como fundamento. Más coherente con esta idea resulta, por tanto, la defensa de la segunda interpretación, por cuanto nos permite la elaboración de una ontología auténticamente heideggeriana, a saber: una ontología del declinar.

Es cierto que en Sery tiempo hay un cierto propósito de «fundamentación», pero ésta presenta una fisonomía particular que posibilita la elaboración de una ontología del declinar ${ }^{72}$. El modo radical en que se plantea la pregunta sobre el ser -como paso previo a la analítica de la existenciaimposibilita una respuesta con rasgos de fundamentación. No es posible asignar un Grund (como principio o razón suficiente), ni el pensamiento puede alcanzar una posición desde la que disponer del ente que debería resultar fundado. Por ello, el ser no puede constitutivamente fundar porque es débil y depotenciado, sin energeia. El «sentido del ser» se entiende mejor como una «dirección» en la que el Ser y el Dasein van encaminados a una sucesiva dislocación, sin posibilidad de hallar una base estable. El Dasein no es el centro fundante ni tiene relación con él; es el hombre postcopernicano que ha sido desplazado del centro hacia la X.

El «sentido del ser» sólo puede ser dado al hombre como «dirección de desposesión y desfundamentación». En consecuencia, el nihilismo y la experiencia del mismo se convierten en la única vía de la ontología. Sin embargo, la ontología del declinar no remite a una sensibilidad pesimista o decadente. Es un discurso concerniente al modo de darse el ser en nuestra experiencia, y éste no se da como fundamento sino como evento (Ereignis). El ser no es lo que deviene, sino lo que nace o muere: es historia de múltiples interpretaciones que posibilita nuestra experiencia de las cosas. El ser no es el objeto inmóvil e inmutable de la ciencia, sino vida-historia, esto es, juego de interpretación, crecimiento y mortalidad. Nuestra experiencia es la de un juego de apariencias, no la del contraste entre el aparecer y el ser. Por ello, la concepción del ser viviente-declinante (mortal) contribuye a entender esta nueva experiencia.

La definición del Dasein como ser-para-la-muerte ayuda, precisamente, a entender el carácter de mortalidad del ser. La mortalidad posee una significación ontológica y hermenéutica; hace imposible toda permanencia

72 Ibíd., p. 52 y ss. 
fundante, luego el ser sólo acontece en la interpretación. «Es, efectivamente, en cuanto mortal que el ser-ahí accede al Ab-grund sobre el que se sostiene toda contextualidad fundante-fundada de su historia: es el ser para la muerte el que revela el continuum histórico como signado, en último término, por una discontinuidad, la del $A b$-Grund. En este sentido deben entenderse, en rigor, expresiones como 'la muerte es el cofre de la nada'. El ser-ahí piensa al ser como diferencia sólo en tanto se proyecta para la propia muerte. (...) Pero el hecho de que la relación con el Ab-grund esté ligada al ser-mortal del ser-ahí quiere decir también otra cosa; que esta relación con el $A b$-grund se articula siempre también como relación con el pasado, del cual proviene de hecho el ser-ahí en tanto mortal. Andenken es, entonces, también 'memoria' en sentido literal, regreso historiográfico sobre la Ueberlieferung. El pensamiento rememorante es pensamiento hermenéutico ${ }^{73}$ 》.

\section{El Centellear del EReignis en el Ge-STELl}

La intención filosófica de Vattimo es «proponer una lectura ontológica, y no sólo sociológica, psicológica, histórico-cultural, de la existencia humana en la condición tardomoderna, posmoderna, tecnológica; en suma, en aquella constelación a la que Heidegger llama con el nombre Ge-Stell ${ }^{4}$ ».

Ge-Stell, en el sentido de imposición del mundo técnico, es el conjunto de la técnica moderna, cuya esencia determina el horizonte del Dasein en el mundo contemporáneo: «Como totalidad del mundo técnico, el Ge-Stell define la condición (la situación) de nuestro específico arrojamiento histórico-finito. Él es también la condición de posibilidad del venir de los entes al ser en esta determinada época». En el Ge-Stell, el hombre es siempre llamado de nuevo a empeñarse en nuevas actividades suscitadas por la provocación de la naturaleza, una provocación entre hombres y cosas. Por ello, el Ge-Stell no es caracterizado por reducirlo todo a Grund (fundamento-fondo), sino por colocar al ser-ahí en una situación de provocación, juego, respuesta. Según Heidegger, el carácter de ahistoricidad que se atribuye al mundo de la técnica, y que consiste en reducir todo a Grund, hace que sea imposible cualquier novedad histórica. Pero esta ahistoricidad del mundo técnico tiene también un valor positivo: «El Ge-Stell nos introduce

73 Vattimo, G., Las aventuras de la diferencia, op. cit., p. 123.

74 Vattimo, Más allá del sujeto, p. 9 y s. 
en el Er-eignis como ámbito de oscilación también y sobre todo en cuanto destituye la historia de su auctoritas, haciéndolo justamente no una explicación-justificación dialéctica del presente, y tampoco una desvalorización relativista de él, sino el lugar de una urgencia limitada, de una universalidad problemática como la del juicio de gusto kantiano» ${ }^{75}$.

Una de las idea heideggerianas sobre la que más incide Vattimo es la de que en la noción de Ge-Stell se vislumbra el concepto de Ereignis ${ }^{76}$, por el que el ser es concebido como evento fundante-desfundante. Es fundante porque determina la condición-posibilidad del venir de los entes al ser. Es desfundante porque esta condición-posibilidad es determinada como privada de todo fundamento. «El Ge-Stell-es decir, la universal imposición y provocación del mundo técnico- es también un 'primer centelleo del Ereignis', de ese evento del ser en el que toda apropiación -todo darse de algo en cuanto algo- se efectúa sólo como transpropiación, en un vertiginoso movimiento circular en el que el hombre y ser pierden todo carácter metafísico. La transpropiación en la que se realiza el Ereignis del ser es, en definitiva, la disolución del ser en el valor de cambio, ante todo en el lenguaje, en la tradición como transmisión e interpretación de mensajes»»7.

75 Vattimo, G., Más allá del sujeto, op. cit., p. 65.

76 En palabras de Heidegger: «La mutua pertenencia de hombre y ser a modo de provocación alternante, nos muestra sorprendentemente cerca, que de la misma manera que el hombre es dado en propiedad al ser, el ser, por su parte, ha sido atribuido en propiedad al hombre. En la com-posición (Ge-Stell) reina un extraño modo de dar o atribuir la propiedad. De lo que se trata es de experimentar sencillamente este juego de propiación en el que el hombre y el ser se transpropian recíprocamente, esto es, adentrarnos en aquello que nombramos Ereignis.», en Identidad y diferencia, «El principio de identidad», op. cit., p. 85. El paréntesis es mío para señalar la palabra que los traductores de la obra emplean para vertir Ge-Stell al castellano. Por su parte, el profesor Pedro Cerezo la traduce por «dispositivo» (vid., p. e., el artículo «Metafísica, técnica y humanismo en Martin Heidegger», Taula, no. 13-14, pp. 31-63, UIB, 1990), mientras que el profesor Félix Duque prefiere la expresión «estructura de emplazamiento» (Cfr., p. e., «Martin Heidegger: en los confines de la Metafísica», Anales del Seminario de Historia de la Filosofía, n. 13, pp. 19-38, Servicio de Publicaciones UCM, Madrid, 1996).

77 Vattimo, G., El fin de la modernidad, op. cit., p. 29. En Más allá del sujeto, p. 63, dice Vattimo también: «El Ge-Stell, que puede representar el máximo peligro para el pensamiento porque desarrolla hasta el final las implicaciones del enrigidecimiento metafísico de la relación sujeto-objeto, en la técnica como organización total, es también el lugar del relampaguear del Ereignis porque la manipulabilidad universal, la provocación y el sacudimiento que lo caracterizan constituyen la posibilidad de experimentar el ser fuera de las 
El acceso al Ereignis se hace posible por la escucha de la esencia (Wesen) de la técnica, en el sentido de «regir», o modo de darse, de la técnica misma. Este pensar en el Wesen de la técnica exige el paso atrás (Schiritt-zurück) que nos sitúa en la totalidad de la historia de la metafísica.

El Ereignis es el acaecimiento apropiador (evento) en el que cada ente aparece como aquello que es en un movimiento de transpropiación. En el Ereignis, por el que los entes vienen al ser, el hombre es apropiado (ver-eignet) al ser y el ser es entregado (zugeeignet) al hombre. El evento del ser es, pues, un juego de apropiación-transpropiación-transposición. «Er-eignis es así el evento en que cada ente es 'propiado', y por tanto aparece como aquello que es, en cuanto está también, inseparablemente, implicado en un movimiento de trans-propiación. El movimiento de trans-propiación concierne, antes que a las cosas, al hombre y al ser. En el Er-eignis, en efecto, en el cual los entes vienen al ser, sucede que el hombre es ver-eignet (apropiado) al ser, y el ser es zugeeignet (entregado) al hombre» ${ }^{78}$.

En el Ge-Stell, hombre y ser "pierden sus caracteres metafísicos y ante todo el carácter que los contrapone como sujeto y objeto» en virtud de una recíproca sacudida ${ }^{79}$. En la metafísica tradicional, hombre y ser han sido determinados como sujeto y objeto. De ahí el surgimiento de las ciencias del espíritu y de las ciencias de la naturaleza. Sin embargo, en la confusión del Ge-Stell, estas determinaciones contrapuestas se pierden: las cosas pierden su rigidez porque son susceptibles de ser planificadas y sujetas a nuevos usos; y el hombre, por su parte, pierde su subjetividad al ser convertido en objeto de manipulación universal. «La universal manipulabilidad -de las cosas y del ser-ahí mismo- liquida los caracteres que la metafísica había atribuido al ser y al hombre; ante todo el de la estabilidad (inmutabilidad, eternidad) del ser al que se contrapone un problemático y deviniente reino de la libertad $\rangle^{80}$.

La experiencia del Ge-Stell es, pues, un ejemplo de fundamentación hermenéutica en cuanto que contiene los dos elementos que constituyen el «Dios ha muerto de Nietzsche»: a) no es un concepto, sino una constelación de pertenencia o evento que destina-determina (bestimmt. entonar)

categorías metafísicas, ante todo la de la estabilidad».

78 Vattimo, Más allá del sujeto, op. cit., p. 60.

79 Vattimo, El fin de la modernidad, op. cit., p. 41.

80 Vattimo, Más allá del sujeto, op. cit.,. p. 62. 
cualquier posible experiencia que tengamos del mundo; y b) pertenecer al Ge-stell funciona como fundamento sólo en cuanto da acceso, no a un Grund absoluto, sino «a un ámbito de oscilación en el que cada apropiación, cada darse de algo en cuanto algo, está suspendido a un movimiento de transpropiación ${ }^{81}{ }^{81}$. El carácter hermenéutico de la fundamentación hace referencia, por un lado, a la condición histórico-finita de las condiciones de posibilidad de nuestra experiencia del mundo (precomprensión históricamente situada) y, por otro, al círculo hermenéutico. En efecto, toda fundamentación tiene un carácter histórico-finito, en tanto que el ser humano es histórico-finito, y acontece en el juego de pasado-presente-futuro de la circularidad hermenéutica. Esto demuestra que no hay fundamento en sí, sino que la fundamentación equivale a interpretación, lo cual no implica la arbitrariedad, sino la recepción de un pasado histórico que va «determinando» el ser de las cosas y el modo de comprenderlo.

Por otro lado, las descripciones del Ge-stell y del Ereignis conectan con las nociones de Sprung (salto) y Schiritt-zurück (paso atrás). En efecto, el pensamiento que olvida el ser como fundamento, que abandona el ámbito metafísico de la representación, se sustrae a la cadena de fundación y salta fuera del ser entendido como Grund. Este salto fuera del ser nos conduce a la «constelación de hombre y ser configurada en el Ge-Stelli. El Ge-Stell que se encuentra tras el salto no es una base estable sobre la que apoyarse o detenerse, sino un lugar de eventualización del ser que experimentamos como ámbito de oscilación. Y el ser es la oscilación misma. «El acceso al ámbito de oscilación adquiere así un ulterior y más explícito carácter hermenéutico; responder a la apelación del Ge-Stell comporta también un salto que nos pone en una relación liberadora con la Ueberlieferung, aquel juego de transmisión de mensajes, de palabras, en que consiste el único elemento de posible 'unidad' de la historia del ser (que en esta transmisión de mensajes se resuelve completamente) $\rangle^{82}$.

En opinión de Vattimo, la meditación heideggeriana sobre el Ge-Stell constituye una primera aproximación hacia una ontología del declinar al hacerse manifiesto el Ereignis como lugar de oscilación. Primero, porque el ser es despojado de sus caracteres metafísicos, apareciendo en su constitución «débil», oscilante in infinitum; segundo, porque a este ser débil se

81 Ibíd., p. 63 y s.

82 Ibíd., p. 65. 
accede sólo mediante una fundamentación hermenéutica, en virtud de la cual los entes vienen al ser en un horizonte histórico-finito que se apoya en una tradición a la que se remonta sin detenerse en un pretendido origen; y tercero, porque a este remontarse in infinitum, y a la oscilación posibilitada por el Ereignis, se accede con un salto en el Abgrund de la constitución mortal del ser-ahí. Esto último quiere decir que el «paso» a la autenticidad por parte del Dasein consiste en decidirse por la propia muerte, decisión que subyace al diálogo liberador con la Ueberlieferung (tradición, en el sentido de transmisión de mensajes en el lenguaje, «la casa del ser»). La única imagen del ser de la que disponemos es la que no es lanzada por la tradición como un juego de transmisiones de mensajes. Y en este juego sólo podemos entrar y salir si somos mortales. Lo más «auténtico» es, pues, ser mortales, ya que asumir la muerte es asumir la única «verdad»: no hay verdad absoluta, no hay fundamento; lo que somos, es fruto de la tradición (o, mejor dicho, del acontecer presenta-actual de la tradición). El pasado es más importante que el futuro porque toda posibilidad se contiene en aquél. Es en el pasado donde podemos encontrar las claves interpretativas, esto es, un nuevo orden de significados, con las que poder concebir el sentido del ser, gracias al cual los entes llegan al ser.

La posibilidad de hablar del ser con relación a los entes viene dada por la diferencia ontológica heideggeriana, la cual, sentencia Vattimo, resulta determinante para comprender el pensamiento de la postmodernidad. Esta diferencia ontológica, sin la que sería imposible desarrollar un discurso filosófico postmoderno, es la relación que une y separa a la vez el ser y los entes. La noción heideggeriana de epoché posee el mismo significado, por cuanto se refiere a la auténtica fundamentación en la estructura del ser: «La epoché heideggeriana es aquel carácter del ser por el cual el ser se da y se oculta al mismo tiempo en el aparecer de los entes (es decir, de las cosas y de las personas que pueblan el mundo) $\rangle^{83}$. El ser se da como la luz dentro de la cual los entes aparecen, por lo cual él mismo se oculta, se sustrae. El ser hace sitio a los entes, dejándolos aparecer, mediante la apertura de un horizonte en el cual éstos llegan al ser. Pero para que el ser pueda hacer sitio a los entes, él a su vez, tiene que retraerse (no llamar la atención sobre sî) y dejarlos libres para que de ellos se pueda decir que son. Es lo que acontece en la historia de la metafísica: «La diferencia ontológica

83 Vattimo, G., Poesía y ontología, op. cit., p. 26. 
es el peculiar carácter del ser por el cual el ser se esconde mientras que deja aparecer a los entes; la metafísica es la consecuencia, no accidental, de este darse-ocultarse y, en este sentido, es destino e historia del ser» ${ }^{84}$. Esta caracterización de la diferencia ontológica sugiere no considerar la época de la metafísica como un acontecimiento más dentro de la diferencia, como si esta fuese una superestructura. «El carácter eventual del ser excluye que su misma eventualidad, y, por tanto, la diferencia, pueda considerarse una super-estructura que vale para toda posible historia; la expresión 'metafísica como historia del ser' debe ser tomada asimismo en el sentido objetivo del genitivo: el ser no es algo o alguien que tiene una historia, con la cual no se identifica completamente; él pertenece totalmente a la metafísica, ésta es su historia porque sólo en ella el ser se da, sucede, se eventualiza» ${ }^{85}$. Pero, cuando Heidegger habla de la diferencia ontológica, no se está refiriendo a la omisión del hecho de que el ser no es el ente, sino a la omisión de la diferencia como problema, de ella en su eventualidad y de la razón de su institución. La necesidad de un pensamiento rememorante, menos factual y representativo, se debe a que de la diferencia no se puede dar cuenta; antes bien, sólo puede ser recordada en su carácter de «evento eventualizado en el horizonte de la historia de la metafísica».

El olvido de la diferencia es el olvido de la metafísica, pero poner fin a la metafísica no equivale a poner fin al ser mismo y a la diferencia. La diferencia heideggeriana entre ser y ente obliga, por lo tanto, a no identificar el ser con el fundamento, luego dicha diferencia es una propuesta de desfundamentación frente a la pretensión de presentificar el ser y otorgar, al mismo tiempo, un carácter de definitividad a tal presencia. Pero la diferencia como desfundamentación tiene también el significado de un descubrimiento de la finitud constitutiva de la existencia, la cual se anuncia

84 Vattimo, G., Las aventuras de la diferencia, op. cit., p. 77. En Poesía y ontología, op. cit., p. 27, dice también Vattimo: «Según Heidegger, es característico de la historia de la metafísica occidental haber transformado la pregunta por el porqué y sobre el origen, con el resultado de haber desviado de su camino al pensamiento, identificando el ser con el ente, olvidando lo que tiene de peculiar y característico, su irreductibilidad al ente, la diferencia ontológica». El ser no puede ser confundido con los entes, ni siquiera como ente supremo. La pregunta por el ser de los entes no es una pregunta por la causa u origen porque no resuelve el problema del ser. La pregunta por la causa u origen del ser remite siempre, e inevitablemente, a un ente, por lo que el problema mismo del ser vuelve a aparecer. 85 Vattimo, G., Las aventuras de la diferencia, op. cit., p. 79. 
(al pensamiento que escucha su llamada) como indisolublemente ligada al ser-para-la-muerte. De este modo, la diferencia ontológica heideggeriana nos conduce, en opinión de Vattimo, al planteamiento de una nueva ontología en la que sea constitutivo del ser el desaparecer y el no imponerse. Tal es una ontología de la decadencia: «El pensamiento de Heidegger responde a una exigencia que la experiencia moderna hace valer más claramente: la exigencia de una ontología regida por categorías 'débiles' $\rangle^{86}$. Evidentemente, esta ontología débíl sólo puede ser asumida por un pensamiento igualmente débil. Esto nos lleva a considerar otro aspecto de la diferencia: la solicitud de la criticidad. La diferencia como destitución de la definitividad de la presencia -es decir, como desfundamentación- es esencial al pensamiento que quiera constituirse en crítico, contra cualquier pretensión de conciliación dialéctica.

De ahí que Ge-Stell («imposición»), que representa el interpelar, provocar y ordenar de la técnica, constituye «la esencia histórica y predestinada del mundo técnico». Una esencia que es el remate de la metafísica: en su afán de dominio del mundo, la técnica proyecta un fundamento racional y racionalizante sobre el mundo y el ser aparece como Grund. Por tanto, el triunfo de la técnica es un momento más dentro del proceso desplegado por la metafísica.

La llamada o la apelación del Ge-Stell supone también una disposición a vivir de forma radical la crisis del humanismo, pero no como un abandonarse a las leyes de la técnica, sino como un pensar en su esencia, la cual no es algo técnico. La esencia de la técnica pone las condiciones para salir de la metafísica y del humanismo (como Verwindung, no como Aufhebung). La técnica hay que verla colocada dentro de la tradición metafísica sin que nos dejemos imponer el mundo que la técnica determina como la «realidad». En consecuencia, opina Vattimo, para que la técnica, ligada a la subjetividad presentificante, pierda su capacidad de impresión de la realidad, es necesario que el sujeto no se conciba como sujeto fuerte: «La crisis del humanismo en el sentido radical que asume en pensadores como Nietzsche y Heidegger, (...) se resuelve probablemente en una 'cura de adelgazamiento del sujeto’ para hacerlo capaz de escuchar la exhortación de un ser que ya no se da en el tono perentorio del Gund o del pensamiento de pensamiento o del espíritu absoluto, sino que disuelve su presencia-au-

86 Ibíd., p. 9. 
sencia en las redes de una sociedad transformada cada vez más en un muy sensible organismo de comunicación $\rangle^{87}$. Este nuevo ser, repetimos, es evento (Ereignis).

El humanismo no representa valores alternativos a los de la técnica porque en la esencia de la técnica se ponen de manifiesto los rasgos que metafísica y humanismo habían mantenido ocultos. Esta revelación significa un momento final para ambos, y si la crisis del humanismo es superación, Verwindung, lo es en el sentido de una exhortación y remisión, por la que el hombre es llamado a recobrarse del mismo. Dicha Verwindung nos traslada a un pensamiento ultrametafísico vinculado a la tradición que nos transmite la metafísica. Esta Verwindung de la metafísica, que no piensa el ser como estructura estable ni como necesidad lógica de un proceso ${ }^{88}$, tiene lugar cuando el hombre «percibe» el centelleo del Ereignis en la llamada del Ge-Stell. Para superar la metafísica, se debe partir de ella y sus conceptos, pues sólo así es posible repensar el ser, de cuyo olvido nos ha advertido la propia historia de la metafísica.

\section{LA DEBILIDAD Y EVENTUALIDAD DEL SER}

De la exposición de los anteriores conceptos heideggerianos puede extraerse la idea que, según Vattimo, vertebra todo el pensamiento de Heidegger y por la que merece ser considerado un precursor de la postmodernidad filosófica: el ser es vida, nacimiento, maduración y muerte, no algo fuerte, eterno y estable. El ser no es lo que permanece, sino lo que siempre deviene, en un proceso continuo de nacimiento u muerte, a través del flujo lingüístico-interpretativo que tiene su fuente en el propio acaecer histórico del hombre. Este nihilismo, base de la ontología del declinar, nos predispone para una crítica a la metafísica occidental y a su noción de sujeto y a la idea de la historia como progreso. En consecuencia, se produce un replanteamiento del pensar y de la filosofía que concluyen en una ontología estética y hermenéutica. Este replanteamiento ontológico y espistemológico, que afecta a la concepción misma del ser humano y a su relación con la realidad, señala la única vía para un pensamiento al final de la crisis de la modernidad.

El pensador italiano aboga por repensar la filosofía desde una concep-

87 Ibíd., p. 45 y s.

88 Berciano, M., «Heidegger, Vattimo y la deconstrucción», op. cit., p. 21 y s. 
ción del ser que sea diversa y débil. Para ello se han de eliminar los caracteres «fuertes» del ser, defendidos por la metafísica: presencia desplegada, eternidad, evidencia, autoridad y dominio. La filosofía no puede ser una ciencia porque no demuestra ningún enunciado. Ella es sólo un «ejercicio de mortalidad», un «discurso 'edificante' o 'estético'» que enriquece nuestra experiencia de las $\operatorname{cosas}^{89}$. No se puede hablar de la verdad, ya que este término alude a nuestro ser-arrojados en un horizonte de comprensión del mundo inscrito en el lenguaje y en la tradición cultural. Se ha de buscar una nueva experiencia «superficial», no platónica, de los valores y de los significados. Afirmar que no hay estructuras fijas o estables, sino acomodamientos, es concebir un ser débil que nos libera. Esto tiene como resultado el que nuestra existencia sea oscilante (expresión de Heidegger), lo cual tiene que ver con la «libertad de espíritu». La filosofía sirve sólo para educarnos en la capacidad de sostener la existencia oscilante y la mortalidad ${ }^{90}$. En palabras del filósofo italiano: «En el término ontología del declinar quieren por ahora hacerse oír estos tres momentos, que me parecen esenciales, de la herencia heideggeriana: la indicación de una teoría positiva del ser caracterizado como débil respecto del ser fuerte de la metafísica, como remontarse in infinitum respecto del Grund; la individualización de la fundamentación hermenéutica como tipo de pensamiento que corresponde a esta no-metafísica caracterización del ser; la peculiar conexión de este modo no metafísico de Wesen del ser con la mortalidad constitutiva del ser-ahí» ${ }^{91}$. Nótese que se habla de individuación de la fundamentación hermenéutica, pues no se trata de una hermenéutica universal, sino particular e histórica. También es una exigencia el individualizar la noción de ser, que pierde su universalidad para convertirse en particular e histórica, sujeta al nacimiento y a la muerte.

Vattimo está de acuerdo con Heidegger en que la tradición metafísica es la tradición de un pensamiento «violento», construido sobre categorías violentas de esencia impositiva. Es por esta razón por la que -según Vattimo- el filósofo alemán puede considerar, a la luz de esta «ontología de la decadencia», el mundo técnico o de la sociedad de masas como el lugar en el que se anuncia el alumbramiento del «nuevo» ser. Siendo el hombre del

89 Vattimo, G., Más allá del sujeto, op. cit., p. 19.

90 Ibíd., p. 23.

91 Ibíd., p. 66. 
mundo técnico quien más ha olvidado la diferencia ontológica, ha experimentado al mismo tiempo un ser en su modalidad «débil». Ello ha comportado también una disolución del sujeto con todas sus características violentas. Este sujeto depotenciado es el que vive el ser-para-la-muerte y está dispuesto a una relación menos dramática con la propia mortalidad ${ }^{92}$. La crítica a la metafísica occidental lleva a Heidegger a proponer un pensamiento ultrametafísico en el que el ser sea tenido en cuenta, recordado siempre como evento. Este concepto de ser es interpretado por Vattimo desde categorías débiles. Pero la crítica a la metafísica no estaría completa sin la crítica a la subjetividad moderna. El resultado es un sujeto postmoderno: un sujeto débil, no violento, capaz de dar cuenta de la pluralidad e inestabilidad del ser.

La crítica de la noción de sujeto realizada por el segundo Heidegger tiene una impronta ontológica ${ }^{93}$. De hecho, la cuestión del sujeto se relaciona directamente con la cuestión del ser, que remite, a su vez, a la cuestión del tiempo. El sentido profundo de este cambio ontológico en el pensamiento heideggeriano radica en el reconocimiento de la insuficiencia de la noción burgués-cristiana de sujeto para interpretar la experiencia histórica del hombre actual. La crisis del sujeto burgués-cristiano (del sujeto trascendental) implica el fin del papel hegemónico de la conciencia en lo que al conocimiento se refiere. Las razones del antihumanismo de Heidegger se encuentran en la concepción humanística del sujeto como autoconciencia, correlato, a su vez, de la caracterización del ser metafísico como objetividad, evidencia y estabilidad ${ }^{94}$. «La primacía del sujeto en la metafísica es función de la reducción del ser a la presencia: el humanismo es la doctrina que asigna al hombre el papel del sujeto, es decir, de la autoconciencia como sede de la evidencia en el marco del ser concebido como Grund, como presencia plena» ${ }^{95}$. El antihumanismo de Heideggeer se manifiesta, por tanto, como anticonciencialismo, esto es, como desconfianza respecto del sujeto de la metafísica moderna.

En las condiciones dadas al hombre en el mundo tardomoderno o postmodero, ha perdido sentido el ideal de un sujeto como conciencia conciliado, cual yo reapropiado. Este ideal posee un carácter de «máscara», de acuerdo con la teoría de la ideología y el psicoanálisis. El sujeto mo-

92 Vattimo, G., Las aventuras de la diferencia, op. cit., p. 9 y s.

93 Vattimo, G., Las aventuras de la diferencia, op. cit., p. 49.

94 Vattimo, G., El fin de la modernidad, op. cit., p. 47.

95 Ibíd., p. 43. 
derno no sólo resulta objetivante, sino también absoluto, atemporal. Con ello, se olvida que el sujeto es una realidad histórica que se configura en su relación con todo aquello que le rodea. Y esta finitud e historicidad del sujeto imposibilita cualquier absolutización del mismo.

La crítica al subjetivismo moderno, caracterizado por consumar la escisión lógica-ontológica sujeto-objeto, encierra una crítica al concepto metafísico de verdad, sustentada en el juicio que profiere el sujeto que conoce, en relación al objeto conocido. El concepto tradicional de verdad considera a ésta una propiedad de las cosas, de ahí que la función del sujeto haya sido siempre la de servir de testimonio de «lo que las cosas son». En consecuencia, todo este subjetivismo ha supuesto la pérdida de la verdad ontológica, el olvido de la diferencia ontológica y la no consideración de la pertenencia del sujeto al ser. No existe una verdad en sí, independiente de un sujeto que trata de conocerla. El hombre es indispensable para que se dé la verdad, para que ésta acontezca. Por ello, la crítica al subjetivismo es una crítica al sustancialismo que aísla ser y pensar en su afán dialéctico. El problema de fondo es, pues, de fundamentación. Pero este problema se resuelve cuando el fundamento se sustituye por el evento (Ereignis). Como ya se ha dicho antes, proponer que el ser es evento es sostener que el ser y el hombre viven en una relación de transpropiación. En palabras de la profesora Teresa Oñate, quien se hace eco del lema de Identidad y diferencia, «el ser es relación de copertenencia constitutiva del ser $\leftrightarrow$ pensar $\leftrightarrow$ hombre9 $\%$. Por lo cual la verdad sólo puede acontecer como desvelamiento, como fruto de la relación de copertenencia (y mutua expropiación) del hombre con el ser.

En consecuencia, la tesis de Vattimo de que el nihilismo y la experiencia del mismo se convierten en la única vía posible de la ontología, parece chocar contra el significado que los textos de Heidegger dan al nihilismo: aplastamiento del ser contra los entes, el olvido del ser que caracteriza a la metafísica occidental, la reducción del ser a valor (sentido Nietzscheano). De este modo, del ser no queda ya nada porque el nihilismo constituye la culminación del olvido del ser en el momento final de la metafísica occidental. El nihilismo heideggeriano está en relación con la ausencia de fundamento que ha propiciado la metafísica tradicional en su olvido de la

96 Oñate, T., «La cuestión del sujeto en el pensamiento de Martin Heideggen», op. cit., p. 278. 
diferencia ontológica. Pero el nihilismo es también resultado del dominio del ser por parte de la subjetividad. En resumidas cuentas, el nihilismo es lo que cabe esperar partiendo de un planteamiento metafísico. No obstante, de este nihilismo de muerte puede brotar un nihilismo de vida, activo, en el que encontrar una nueva ontología, un nuevo modo de «fundamentación». Entraríamos, así, en un pensamiento ultrametafísico, al que se accede por medio del Andenken y cuyo medio es la ontología hermenéutica.

El pensamiento que piensa la diferencia como diferencia es Andenken, que significa, primeramente, recuerdo, memoria, rememoración, y entiende la historia del ser como evento del ser (y no como repetición de una superestructura inmutable). «Andenken es el pensamiento que, al recordar la diferencia, recuerda al sen ${ }^{97}$. Pero no hay que entender esta rememoración como un hacer presente un no-ya presente que ha estado antes presente. Recordar el ser no es un volver a hacerlo presente, puesto que nunca ha estado presente; su recuerdo es, más bien, una despedida del ser. El $A n$ denken es el pensamiento que deja de lado al ser como fundamento y llega a pensar el Anwesen como Anwesenlassen (que se encamina a pensar realmente el ser) porque la memoria es el modo de pensar la Schickung, el envío del ser, como envío. El envío del ser es el dar del «Es gibt», el dar mismo que se retrae y sustrae en favor de la presencia del ente que él deja ser. El pensamiento de la fundamentación se concentra sólo en el ente y en su ser como ser presente, sin pensarlo en su proveniencia. Este pensamiento fundante se relaciona con su objeto de dos modos: la presentificación y la representación, siendo el representar el modo de ser del pensamiento en la época en la que el ser se da como objetividad.

El «salto hacia atrás» heideggeriano es el salto del pensamiento metafísico-representativo al pensamiento del ser como rememoración. La rememoración es un recordar lo originario, esto es, al ser como la diferencia; es un pensar al ser como lo diferente al ente, sin posibilidad de que sean identificados el uno con el otro. El Andenken, por tanto, hace diferir a los entes y abre las diversas dimensiones del mundo. Pero la posibilidad de acceder a lo originario es sustentada por la relación que se mantiene con el silencio. El hablar (desde el pensar) auténtico, el que profiere la palabra auténtica, la inaugural, hace acaecer nuevas verdades (o nuevas aperturas de horizonte históricos) porque está en relación con lo otro del significan-

97 Vattimo, G., Las aventuras de la diferencia, op. cit., p. 141. 
te, con lo otro del lenguaje: el silencio ${ }^{98}$.

Existe una relación entre Andenken y Ge-Stell, aunque sean conceptos opuestos y contradictorios ${ }^{99}$. Andenken es el pensamiento rememorante situado en una posición distinta del olvido metafísico del ser. Es el pensamiento que da cuenta de la diferencia ontológica. Ge-Stell (im-posición) describe la «constelación» en la que se halla el hombre moderno en el momento en que se produce el triunfo de la técnica y la época de la metafísica ha llegado a su final. Es, pues, el «conjunto del Stellen o todo el situar que caracteriza al mundo técnico: la condición que provoca al hombre para que confiera al ente nuevas «ocupaciones», mediante la imposición del cálculo y la planificación. Aunque el Ge-Stell obliga al pensamiento a ser Andenken, no hay que ver aquí, piensa Vattimo, la tesis «camino del Ge-Stell hacia el Andenkenn», pues eso equivale a convertir a Heidegger en un pensador que siente nostalgia por un mundo de relaciones «auténticas» frente a la nivelación y deshistoricización provocada por la técnica. En Heidegger, por el contrario, hay una actitud de valoración positiva de la técnica (no es sólo un producto alienante) en cuanto que hace posible la superación de la metafísica. Pero esta superación de la metafísica no implica la superación de toda rememoración para que el hombre, simplemente, se adecue a (o asuma) la provocación de la deshistorización tecnológica del mundo. Aunque la técnica es el destino del hombre moderno, este destino no le imposibilita para que se arraigue en la historia humanística, sino que más bien le impele a ese arraigo por medio de la repetición de la experiencia humanística. Se trata, pues, de ir «hacia el Andenken en él y a través del Ge-Stelli.

La rememoración del pensamiento ultrametafísico de Heidegger no coincide, de ningún modo, con la dialéctica hegeliana, ni siquiera con una inversión de la misma. Por ello, Andenken es el pensamiento que vuelve sobre la historia y se asienta en la tradición. Es, por tanto, un pensamiento hermenéutico que no se detiene en una presencia fundante, sino que se remonta in infinito en la cadena de acontecimientos históricos. Se trata de un pensar el ser como Anwesenlassen, esto es, recordando el carácter epocal del ser (de acontecimiento) y situándolo en la concatenación histórica de acontecimientos. Este pensar rememorativo indica, según Vattimo, el

98 Vattimo, G. Más allá del sujeto, op. cit, p. 74 y s.

99 Vattimo, G., Las aventuras de la diferencia, op. cit., p. 140 y s. 
pensar post-moderno, por cuanto se aleja de toda pretensión fundamentadora al estilo de la metafísica. Es más, «el Andenken asume dentro del pensamiento postmetafísico la función que era propia de la fundamentación metafísica» ${ }^{100}$. Por esta razón, el Andenken propicia una ontología hermenéutica y estética en el marco de un pensamiento postmetafísico que no olvida la diferencia ontológica. Puesto que rememorar la diferencia entre ser y entes significa apropiarse del horizonte dentro del que somos arrojados, aunque dicha apropiación no sea nunca completa, el resultado de la reflexión sobre la diferencia ontológica no puede ser otro que el pensamiento hermenéutico. Dicho pensamiento es un esfuerzo por construir el sentido de lo que está presente partiendo de sus conexiones con el pasado y el futuro posible.

La hermenéutica no es un hacer presente la tradición ni reconstruir lo originario de las cosas para una mejor apropiación. La tradición no nos aporta un punto firme sobre el que apoyarnos; más bien nos empuja a remontarnos in infinito a los horizontes históricos en los que nos encontramos y desde los que podemos captar el sentido del ser. ${ }^{101}$. Pero -para Vattimo- se trata de un ser cuyo sentido es el de la debilidad y la desvanecencia: «Este sentido (del ser), que se nos da vinculado con la mortalidad, con la transmisión de mensajes lingüísticos entre las generaciones, es lo opuesto de la concepción metafísica del ser entendido como estabilidad, como fuerza, como energeia; trátese de un ser débil, declinante, que se despliega desvaneciéndose.... ${ }^{102}$. De este modo, lo que libera no es remitir a un Grund, sino saltar al abismo de la mortalidad.

La ontología hermenéutica puede definirse, entonces, en base a tres elementos constitutivos: el rechazo de la objetividad como ideal del conocimiento histórico (es decir, el rechazo del metodologismo de las ciencias positivas), la generalización del modelo hermenéutico a todo el conocimiento, histórico o no, y la lingüisticidad del ser ${ }^{103}$. Estos tres elementos se pueden reconducir a la noción básica de círculo hermenéutico, el cual muestra la pertenencia recíproca de «sujeto» y «objeto» de la interpreta-

100 Vattimo, G., Más allá del sujeto, op. cit., p. 103.

101 Ibíd., p. 108. «En virtud de ese remontarse in infinito y del carácter fluido de los horizontes históricos lo que se recuerda es el sentido del ser». Queda deshecha cualquier interpretación relativista o historicista.

102 Ibíd., p. 108.

103 Vattimo, G., Las aventuras de la diferencia, op. cit., p. 25. 
ción. La interpretación es, pues, la articulación de la precomprensión. La razón de esta constitución de la ontología hermenéutica se encuentra, según Vattimo, en que ésta "parte del problema del conocimiento histórico; la reflexión sobre la insuficiencia del modelo científico-positivo respecto del conocimiento histórico y de las ciencias del espíritu conduce a una crítica general del modelo positivista del método científico: la hermenéutica adelanta una reivindicación de universalidad, que se concreta y a la vez se funda en la teorización de la lingüisticidad del ser» ${ }^{104}$. Es de vital importancia comprender que el ser pertenece originalmente al lenguaje, con lo cual el ser es historia, e historia del lenguaje. Por ello, la interpretación de la historia, y del conocimiento en general, no es un proceso de desciframiento, sino un diálogo en el que la verdadera Sache («cosa del pensar») es la fusión de horizontes en la que el mundo, junto con sus «objetos», se reconstruye continuamente en el ser con el concurso de la interpretación. De esto resulta que : a) el modelo de objetividad de la ciencia histórica es sustituido por el modelo dialógico ${ }^{105}$, esto es, por el modelo del acontecer histórico, y b) la interpretación es un proceso indefinido en tanto que cada respuesta hace surgir nuevas preguntas en una nueva llamada.

En conclusión, en el Ge-Stell se anuncia el Ereignis, con lo cual el fundamento se torna en evento: el ser (y la verdad) es evento. El ser no es una estructura estable, fija, inmutable, tal ente estático e inerte, sino una realidad viva e histórica que acontece epocalmente. Consecuentemente, la verdad tampoco es una propiedad de las cosas o de los entes. Como el ser, la verdad acontece también epocalmente, gracias a la relación de copertenencia que el ser mantiene con el hombre, ente finito e histórico. A la verdad del ser, a su sentido, sólo se accede por medio del diálogo con la historia y la tradición. De ahí que el pensar postmoderno sea un pensamiento rememorante, dialógico, que salta hacia atrás y hacia adelante continuamente, que retorna sobre sí. El Andenken es pensamiento hermenéutico, para el que la verdad es desvelamiento de lo velado, en el sentido de lo que no es todavía, pero es algo «real». La obra de arte, en el momento actual, sería el lugar privilegiado desde el que comprender mejor el sentido del ser y de la verdad, puesto que la verdad posee un estatuto estético y poético.

104 Ibíd., p. 26.

105 Ibíd., p. 31: «A la ontología hermenéutica es consustancial una visión de la historia como historia del lenguaje y como diálogo abierto». 


\section{Acerca de la interpretación que Vattimo hace de Heidegger}

Tomando como base la reflexión vattimiana sobre el carácter ontológico de la afectividad, el profesor Armando Segura sostiene la tesis de que la interpretación que el filósofo italiano hace de Heidegger es la más correcta. Esto es, de Heidegger sólo cabe una lectura postmoderna-debolista. En su opinión, las claves esenciales del primer Heidegger se mantienen en el segundo y ya están expuestas en Kant y el problema de la metafísica, obra en la que se ve cómo Heidegger invierte el orden de las facultades del conocimiento, de modo que el entendimiento se subordina a la sensibilidad. Este planteamiento tiende a la prioridad de la receptividad sensible sobre la actividad intelectual. Es lo que Vattimo llama «pensamiento débil». Es débil porque es sensible, sentimental y afectivo. Esta sería la verdadera clave que explica todo Heidegger. Por su parte, Vattimo aportaría muy poco al asunto, salvo un extracto o síntesis del mismo. En su obra Heidegger, en el contexto del pensamiento «debole» de Vattimo, dice Armando Segura: «Heidegger profundiza en la contingencia su carácter efímero, su caducidad, de manera que, en el fondo, toda la operación fenomenológica existencial conduce a una devaluación cada vez mayor de la existencia. En este sentido y a nivel de Sein und Zeit, cabría entender a Heidegger como uno de los pilares de del llamado 'pensamiento débil'. A la soberbia del hombre racionalista, se le enfrenta la superficialidad y vacuidad del hombre como 'moda' esfímera. (...) Si el pensamiento débil apuesta por la fragmentariedad de la existencia y deja la 'sustancia' para la metafísica, es porque considera que la metafísica es irrelevante para la antropología, es decir, para el hombre. ¿Qué es, pues, lo relevante?¿Qué es la sustancia? Lo débil, lo pasivo, lo que se autoinflige impresiones. La sustancia metafísica y el objeto científico están en los márgenes de lo humano, son como sus accidentes. / Lo humano, en cuanto tal, es el principio de inhesión de aquellos fragmentos, es decir, de la metafísica y la ciencia. La racionalidad, como ya adelantábamos, se convierte en la servidora de la imaginación y el concepto, en servidor del tiempo. En último término, el tiempo, tal como hay que entenderlo en Heidegger, como autoafección, es la sustancia de la razón, que se comporta respecto a aquél como su accidente» ${ }^{106}$. El sentirse (autoafección) mal desde la originaria autenticidad (el ser-para-la-muerte)

106 Segura, A., Heidegger, en el contexto del pensamiento «debole de Vattimo», Granada, Servicio de Publicaciones de la Universidad de Granada, 1996, p. 43 y s. 
configura la estructura temporal de nuestra existencia y nuestro modo de comprender el ser. La inteligencia se subordina a la imaginación poética y al sentimiento estético que la realidad despierta. Desde esta perspectiva, Vattimo, para quien Heidegger ha sabido superar los extremos del logicismo y del historicismo, es presentado como mero divulgador de la hermenéutica y su «pensamiento débil» es considerado un reducto de la analítica de la existencia auténtica que emprende Ser y tiempo.

Por otro lado, tenemos la opinión de Modesto Berciano, para quien Vattimo, a pesar de inspirarse constantemente en Heidegger, «presupone una interpretación de Heidegger que a veces va más allá de las afirmaciones explícitas de éste e incluso contra las mismas ${ }^{107} \gg$. Desde su punto de vista, el filósofo italiano ha interpretado a Heidegger en clave postmoderna porque ha hecho una lectura parcial y fragmentaria de las obras del filósofo alemán. Esto ocurre, sobre todo, cuando Vattimo liga exclusivamente el Ereignis al Ge-Stell y reduce el evento a la constelación ser-hombre ${ }^{108}$. Para Modesto Berciano «el evento es más que la constelación ser-hombre», pues «en el evento está el hombre de manera ek-stática, como lugar de la iluminación, como «usado», como «pastor del ser», para llevar al lenguaje y al pensar el habla o el lenguaje del evento y del ser, correspondiendo a ese hablar originario ${ }^{109}$ ». Pero es sobre todo la lectura nihilista que Vattimo hace del pensamiento de Heidegger el aspecto más controvertido de su interpretación. Berciano opina que Vattimo se ha excedido al hablar de nihilismo en Heidegger porque del filósofo alemán «no se puede hablar sin más de una carencia de fundamento (Grund), aunque éste sea abismo (Ab-grund) y no sea ni conocido ni conceptuable ${ }^{110} »$.La idea de destino (Geschik) que maneja Heidegger se opondría al nihilismo, pues el envío del ser (que envía, se envía y sigue enviándose) responde más a una falta de conocimiento acerca de lo que es el ser que a una falta total de fundamento. La idea del destinar del ser señala a lo imprevisible, lo inaprehensible, lo oculto, por lo que se opone a la subjetividad moderna y a su pretensión de asir el ser reduciéndolo a lo objetivo, lo presente y lo calculable. Esta idea de destino representa en Heidegger el intento de superar el nihilismo

107 Cfr. Berciano, M., «Heidegger, Vattimo y la deconstrucción», op. cit., p. 17.

108 Ibíd., p. 28.

109 Idem.

110 Ibíd., p. 31. 
de la técnica al descubrirse el «sentido del ser». Por esta razón, el concepto de evento tampoco puede implicar la defensa de un nihilismo. El evento viene a resultar el destino que forma una historia que adquiere sentido cuando se reconstruye lo que el evento destina. No posible aceptar un nihilismo heideggeriano porque el fundamento que Heidegger rechaza se refiere es algo concreto y conocido, pero aceptaría, en el fondo, otro tipo de fundamento, el cual resulta un abismo para nuestra indigente capacidad de conocer ${ }^{111}$.

Finalmente, concluye Berciano diciendo que la recuperación heideggeriana de la metafísica no puede ser, como piensa Vattimo, nihilista, por el sencillo motivo de que dicha superación-recuperación desemboca en el Ereignis, concepto que no admite, según se ha visto, una interpretación nihilista. Pero hay más. A la insuficiente comprensión del concepto de Ereignis sigue la incomprensión del concepto de Andenken: «Ni Andenken es sobre todo rescatar monumentos, ni es cierto que Heidegger se limite a recorrer los grandes monumentos de la historia. Heidegger busca en la historia lo no pensado y proyecta eso aún no pensado también hacia el futuro. Todo esto es complejo, pero es posible precisamente por la cercanía de hombre y ser en el evento. Una vez más vamos a parar a este concepto fundamental y una vez más quisiéramos ver en la interpretación que Vattimo hace de él su insuficiente visión del Andenken. Si el evento se queda flotando como un movimiento vertiginoso, Andenken podrá limitarse a recordar y coleccionar monumentos. Pero si el evento es acaecer de una apertura en la que son dados ser y tiempo, hombre y ser, tierra, cielo y dioses, y en la que el hombre es el lugar ek-stático de la apertura, el decir y el pensar el ser por parte del hombre podrá ser algo más que reunir amontonando lo dado en los monumentos históricos» ${ }^{112}$. Andenken no es un simple rememorar el pasado e interpretarlo al objeto de reformular el legado de la la tradición (monumentos) de un modo nuevo y diferente. Tal no es el pensamiento de Heidegger, para quien el hombre puede ver la verdad del ser en la historia por la relación de copertenencia que mantiene con el ser. En virtud de dicha relación, el hombre se sitúa en la iluminación que acaece en el evento y está en disposición de recibir la voz o el envío (destino) de éste ${ }^{113}$. Por

111 Ibíd., p. 32.

112 Ibíd., p. 37.

113 Ibíd., p. 38. 
todas estas razones, Berciano no cree que Vattimo interprete debidamente a Heidegger. Incluso, cree que se desvía de la senda trazada por éste. De hecho, su intento de salvar un discurso ontológico, construir un sentido o fundar opciones éticas, proponiendo un pensamiento débil, que se caracteriza por su provisionalidad y contradictoriedad, no concuerda con la visión que Heidegger posee del pensar: un camino en construcción que sirve para caminar, encaminar y replantear continuamente preguntas para seguir haciendo camino ${ }^{114}$. Desde luego, si Heidegger es postmoderno, no lo es según la interpretación que Vattimo hace de él.

Hay una vía intermedia entre ambas lecturas: Heidegger no es «superficial»; tampoco Vattimo es un simple lector «interesado» de éste. No hay duda de que el pensamiento heideggeriano ha sido un antecedente importante de la postmodernidad filosófica, y Vattimo lo ha sabido exponer con profundidad, llevándolo a sus últimas consecuencias. Un mérito importante suyo ha sido el recuperar el discurso ontológico para el pensamiento actual. Esta opinión se corresponde con la otra lectura posible sobre la interpretación que el filósofo italiano hace del filósofo alemán. La podemos encontrar en la obra de la filósofa Teresa Oñate: El retorno griego de lo divino en la postmodernidad. Una discusión con el nibilismo de Gianni Vattimo, una aportación importante por ser una exposición fecunda y esclarecedora del pensamiento vattimiano, entablando al mismo tiempo una discusión con él centrada en la cuestión de la interpretación crítica del nihilismo para Nietzsche, para Heidegger y para el propio Vattimo. Siguiendo esta línea, se puede estar de acuerdo o no con la interpretación que Vattimo hace de Heidegger como precursor de la postmodernidad; sin embargo, hay que reconocerle el esfuerzo de repensar a Heidegger con el fin de recobrar el discurso ontológico para el pensamiento actual. Gracias a ello, la postmodernidad filosófica es entendida no como una simple y vulgar afirmación de un relativismo y un nihilismo pesimista y decadentes. En su lugar, el pensamiento postmoderno es un nuevo intento de pensar la «realidad» desde el sentido del ser, al que se accede por vía estética y hermenéutica. Aunque, para ello, hay que renunciar al pensamiento violento de la metafísica subjetivista tradicional moderna y optar por un pensar menos violento, esto es, débil. Sólo así el ser queda libre de la opresión del sujeto y se le permite acontecer en el devenir de la historia, en las relaciones hu-

114 Ibíd., p. 45. 
manas y en el conjunto de relaciones con toda la realidad.

\section{CONCLUSIÓN}

La postmodernidad, vista por Vattimo, no es aquello que viene después de la modernidad, no es un pensamiento post-positivista, post-racionalista, post-idealista o post-historicista, en el sentido de una interpretación del pensamiento moderno. Es ruptura con la modernidad sin la pretensión de rebasarla para llegar a una existencia y pensamientos nuevos y superiores. No existe el progreso entendido como conquista de fundamentos últimos. Por el contrario, la postmodernidad anuncia la negación de las estructuras estables del ser, además de la unidad y finalidad de la historia. Gran parte de la responsabilidad del surgimiento de esta nueva visión existencial e intelectual la tiene, en su opinión, Heidegger, cuya filosofía del Ereignis sugiere una interpretación eventualista del ser.

Sin embargo, cabe una objeción contra este planteamiento de la historia de la filosofía. Si la postmodernidad filosófica se anuncia a lo largo de toda la historia del pensamiento como un destinar que ha llegado en la actualidad a su plena manifestación en forma de revelación acerca de cómo concebir el ser y el pensamiento, ¿no está cayendo en el mismo hegelianismo que denuncia? ¿Acaso no presenta la postmodernidad como un movimiento de superación de toda la filosofía anterior? ¿Es que no llega a afirmar que por más que se luche por encontrar el fundamento metafísico último de la realidad, por más que se quiera reforzar el papel del sujeto en relación con la realidad, por más que se quiera alcanzar la verdad absoluta y por más que se crea que la historia es un proceso unitario tendente a un fin, las condiciones de la época actual nos informan, de una vez para siempre y de manera incontestable, de que todas estas pretensiones son imposibles? ¿Es la adopción de un pensamiento y ontología débiles la solución última y definitiva a todos los errores filosóficos del pasado? ¿Es la concepción del ser como evento una conquista intelectual definitiva?

Hay dos respuestas posibles a estas preguntas: una afirmativa y otra negativa. En ambos casos debemos decir que, entonces, la postmodernidad no es ni puede ser la última etapa filosófica; antes bien, ésta debe ser superada en virtud de su propio presupuesto, a saber, que no hay nada definitivo ni último. De otro modo, se revelaría como una filosofía última y definitiva. En consecuencia, el pensamiento débil daría muestras de una 
gran fortaleza al haber sido capaz de vislumbrar todo el devenir filosófico hasta dar con su desarrollo último, además de haber sido también capaz de comprender toda la historia de la metafísica y descubrir cuál es el sentido auténtico del ser que ha ido desvelándose a lo largo de todas las épocas: su manifiesta e innegable eventualidad.

Puede que la propia inconsistencia e inanidad del pensar postmoderno, capaz de engendrar un estado de insatisfacción, de angustia y de desesperación en el hombre como nunca antes se había visto, constituya un nuevo aviso o anuncio del ser, un ser que reclama más consistencia, más realidad más allá de la contingencia histórica y del modo afectivo-artístico de acceder a él. Quizás quepa decir ahora que la postmodernidad nos ha mostrado las consecuencias últimas de la filosofía moderna. Quizás sea el momento de emprender una nueva Verwindung. Tal vez sea el momento de que el pensamiento rememore o haga memoria de todo el desarrollo histórico-metafísico hasta el presente y juzgue si la metafísica ha sido un error o si, por el contrario, ha sido un error el superarla hasta apagar su vocación de búsqueda de fundamento. La época actual de imposición técnica y de dominio de los mass media, aunque constituya una constelación propicia para manifestarse el ser como evento mutable y finito, tiene como contrapartida el peligro de que nuestra relación con el ser esté mediada por los medios de comunicación y por nuestra forma de producir, teniendo como resultado una realidad enajenada y acallada por el terrorismo mediático y la tecnocracia salvaje que acaban imponiendo su visión del ser. Un pensamiento débil no puede hacer frente a este peligro real de pérdida de libertad y de sentido vital.

Por otro lado, una salud débil no implica la ausencia total de la salud. Del mismo modo, un pensamiento débil no implica la ausencia de una realidad con un ser propio. Un cuerpo de salud frágil no está necesariamente privado de salud, por cuanto ésta puede ser potencialmente recobrada. Que la inteligencia humana, su capacidad de pensar y acceder al ser, sea débil, no tiene por qué presuponer la privación total de una verdad que venga exigida por su propia naturaleza y que es dada de antemano por aquello que es pensado.

Sustituir la metafísica por la hermenéutica, el ser por el evento, es caer de nuevo en un proceso de imposición óntica en el que el sentido de «lo que es» está determinado por la interpretación de un sujeto nuevamente 
«fundante». ¿Se puede afirmar que esto es una nueva forma de subjetivismo? Decir que el ser es evento dado cultural e históricamente conlleva el renunciar a la pregunta por el «qué de las cosas» en favor de la del «cómo las pensamos-interpretamos». Se trata de un cambio de estrategia no carente de arbitrariedad y decisionismo. Nada impide que las cosas sean por lo que son en sí mismas, que la realidad propia e inalienable tenga un ser propio independiente de cómo el ser humano se relacione con él. De hecho, en esta época de disolución de la existencia y la consecuente caída al abismo, se oye también el grito del ser reclamando su carácter fundante. Que nuestro pensamiento sea débil es una cosa y otra distinta es que el ser de lo real sea débil y evento epocal finito y mudable. El cómo pensemos la realidad no puede determinar el ser propio de la realidad pensada. Bajo la propuesta de una ontología débil subyace otra forma de olvido del ser, aunque con una diferencia: si el olvido de la metafísica favorecía a los entes, en el caso de Vattimo la primacía la tiene la interpretación que se tiene del mismo. De un ser cosificado se pasa a un ser interpretado.

Aunque Vattimo haya sabido llevar el pensamiento de Heidegger hasta sus últimas consecuencias, tal vez va demasiado lejos al interpretar el Ereignis en clave de evento. Acierta, sin embargo, en retomar la crítica al olvido del ser por parte de la metafísica y a su error de cosificarlo en los entes. La cosificación se manifiesta cuando el ente se identifica con el ser, éste se convierte en causa y fundamento de aquél, y el ente adquiere las propiedades de estabilidad e inmutabilidad. La diferencia ontológica recuperaría el carácter histórico del ser, cuyo sentido no puede ser abordado por la metafísica, sino por la exégesis hermenéutica. Al ser del ente, por no tratarse de un ente, se llega por la vía de la interpretación histórico-finita, propia de un pensamiento débil que asume una ontología débil, declinante. De ahí el predominio de lo ontológico (sentido) sobre lo óntico (cosa). La ontología apunta al decir de los entes, no a su constitución entitativa. El ser del ente está condicionado por el logos histórico-cultural-finito, el cual abre un campo de interpretación infinita. De los entes decimos que son (por ejemplo, esto «es» un ordenador), pero en este venir al ser (existencia) de los entes lo importante es el decir mismo con toda su carga histórica-cultural-finita que lleva consigo, gracias a la cual se gesta una fundamentación hermenéutica con proyección infinita, como infinito es el horizonte de significado. La existencia no hallaría su sentido en el existir 
mismo de los entes como fundamento óntico, sino como «fundamento» onto-histórico-dialógico, de ahí la eventualidad del ser. Sin embargo, una cosa es decir que el ser no es fundamento del ente porque el ser y el ente no son lo mismo y, por tanto, éste no puede dar razón de su existencia, y otra distinta que, por la misma razón, el ser es evento epocal. No veo, pues, acertado deducir esta eventualidad de los escritos de Heidegger, quien, en mi opinión, critica una idea de fundamentación heredera de la modernidad: «sustancia es lo que es en sí y por sí» (Descartes), «ser es ser percibido» (Berkeley), «ser y pensar son lo mismo» (Hegel). Lo que viene a decir es que el sentido de «que es» no es dado por el «qué es», sino por el pensar que transciende la cosa del ente y capta el darse del ser como algo distinto a lo dado por el ente en un ejercicio de diálogo con la tradición a través del tiempo.

Con todo, debo reconocer importantes logros filosóficos al postmodernismo vattimiano. En primer lugar, la crítica a la modernidad y, más concretamente, a su pensamiento racionalista, siempre deseoso de fundamentar el ser en el sujeto cognoscente. Aunque el pensamiento débil no sea la solución, al menos ha contribuido a debilitar el subjetivismo moderno y ha abierto la puerta a una nueva era ontológica en la que el ser ha ganado más protagonismo. No obstante, esta afirmación tiene que ser matizada. La ontología que propone Vattimo sigue poniendo más el acento en la relación que el ser humano histórico-finito tiene con la realidad que en la realidad misma, la cual no piensa que deba ser entendida como algo dado, fijo e inmutable al modo en que es concebida por la metafísica, que habla de ente, sustancia o cosa en sí. Por esta razón considera preciso un lenguaje (Ereignis, evento, sentido) y un método (hermenéutica) nuevos, capaces de posibilitar la comprensión de lo que acontece en la tarea-cosa del pensar, caracterizada por una relación-encuentro vivo, histórico y finito entre el pensar y lo pensado, entre pensamiento y realidad.

Otra contribución importante es la crítica a la idea hegeliana de la historia como progreso. Vattimo no atribuye ningún fin al devenir histórico, por lo que tampoco cree que la historia marche en dirección hacia un progreso que se va consolidando en cada época. Presuponer esto es proponer un fundamento/fin trascendente al que tiende, consciente o inconscientemente, el ser humano. Estoy de acuerdo con su crítica a la idea de que cada época es un desarrollo de la anterior, puesto que lo que está por 
venir o ha llegado no tiene por qué ser superior a lo pasado, ni la filosofía última más verdadera que las precedentes. Cada época es nueva, diferente. Ahora bien, se puede objetar a Vattimo que esto no tiene por qué excluir la existencia de un fin moral, político o sobrenatural que guíe el devenir humano. Precisamente porque el pensamiento es débil, debemos apoyarnos en el legado de la tradición filosófica y religiosa. Aun así hay implícito en su propuesta una revalorización de la tradición como lugar en el que captamos el sentido del ser y de lo que somos. Ningún pasado es superado, sino asumido para el presente con vistas al futuro, sin que ese futuro sea superior en logros intelectuales, culturales, morales o políticos. Es en la tradición donde podemos encontrar el significado de lo que es el fin de la historia humana. La tradición se desarrolla en un tiempo en el que pasado-presente-futuro constituyen una unidad. Cada tiempo nuevo es, con sus aciertos y errores, diferente, no superior.

De todo lo anterior podemos extraer la idea de que el ser no es algo estático, cósico; es, más bien, un acontecer en un tiempo en esencia narrativo en el que vive y se expande. Según esto, el ser no es pensado como objeto, por lo que lo pensado tampoco es una cosa. Es decir, el concepto objetivo no puede ser otra cosa en lugar de la concebida con la que conocer a aquello que representa. Una representación mental no puede considerarse un objeto mental -frente a un sujeto- por medio del cual conocer el ser extramental, como defiende el representacionismo moderno. Sujeto cognoscente y objeto conocido quedan disueltos como entidades epistemológicamente opuestas. Según la clásica sentencia aristotélica, el que conoce y lo conocido son lo mismo en el acto de conocer. O lo que es lo mismo: el ser se da al hombre y éste lo recibe sin pretensiones fundamentadoras, dada la naturaleza débil de su pensamiento. ¿Hay en la postmodernidad vattimiana una mirada atrás hacia el origen de la filosofía?

En mi opinión el ser se manifiesta como evento cuando no se lo deja darse, cuando el hombre-sujeto lo convierte en objeto de sus personales interpretaciones. Entonces, ni el pensamiento ni la ontología son tan débiles. 
REFERENCIAS BIBLIOGRÁFICAS:

Berciano, M., «Heidegger, Vattimo y la deconstrucción», Anuario Filosófico, 1993 (26), pp. 9-45.

Heidegger, M., Tiempo y ser, Tecnos, Madrid, 1999.

Oñate, T., «Heidegger, hó Skoteinós [El obscuro]. La ontología Estética del Espacio-Tiempo tras la Kehre», Estudio Preliminar a El segundo Heidegger: Ecología. Arte. Teología, Dykinson, Madrid, 2012.

Vattimo, G., Poesía y ontología, Universitat de Valencia, Valencia, 1993.

Vattimo, G., Introducción a Heidegger, Gedisa, Barcelona,1995.

Vattimo, G., Más allá del sujeto. Nietzsche, Heideggeer y la hermenéutica, Paidós, Barcelona, 1992.

Vattimo, G., El fin de la modernidad, Gedisa, Barcelona, 1993.

Segura, A., Heidegger en el contexto del pensamiento «debole» de Vattimo, Universidad de Granada, Granada, 1996.

Antonio Bueno GonzÁlez es licenciado en filosofía por la Universidad de Granada y ha cursado un máster en Historia de la Filosofía por la Universidad Nacional de Educación a Distancia (UNED).

Lineas de investigación:

Heidegger, Historia de la Filosofía, Postmodernidad, Vattimo

Publicaciones recientes:

- La influencia de Heidegger en la postmodernidad, según Vattimo, Madrid: Universidad Nacional de Educación a Distancia (2012). Trabajo fin de Máster. Accesible en : http://e-spacio.uned.es/fez/view/bibliuned:masterFilosofiaHistoria-Abueno

Dirección electrónica: abugo2000@yahoo.es 